\title{
СИНТЕЗ, ВЛАСТИВОСТІ ТА СКРИНІНГ БІОЛОГІЧНОЇ АКТИВНОСТІ S-ЕСТЕРІВ ТІОСУЛЬФОКИСЛОТ І 3 3,4-ДИЗАМІЩЕНИМИ АРИЛЬНИМИ ФРАГМЕНТАМИ
}

\author{
Баранович Д. Б., Лубенець В. I.
}

\section{ВСТУП}

Суттєвий внесок у розвиток теоретичної та прикладної органічної хімії зумовив прогрес хімії сульфуровмісних сполук. Здатність сульфуру перебувати в різних ступенях окиснення дає низку моно- та дисульфуровмісних речовин ${ }^{1}$, серед яких $\mathrm{S}$-естери тіосульфокислот $\mathrm{RSO}_{2} \mathrm{SR}^{\prime}$ займають важливе місце як ефективні сульфенілюючі та сульфонілюючі реагенти ${ }^{2}$ та як сполуки 3 широким спектром та високим індексом біологічної активності ${ }^{3}$.

Висока реакційна здатність S-естерів тіосульфокислот є результатом особливостей будови тіосульфогрупи $\left(-\mathrm{SO}_{2}-\mathrm{S}-\right)$, передусім унаслідок високої полярності зв'язку S-S, який суттєво залежить від природи кислотного і тіольного складників, що у свою чергу впливає на їхню біологічну активність i реакційну здатність ${ }^{4}$ та визначає сферу можливого практичного застосування.

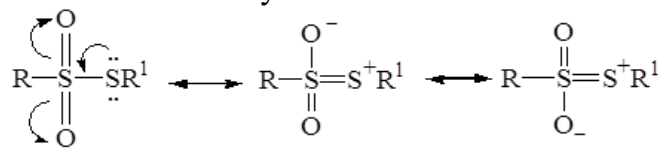

\footnotetext{
${ }^{1}$ Thiosulfonates as Emerging Reactants: Synthesis and Applications Adv. Synth. Catal / P. Mampuys et al. 2020. 362. 3-64. DOI: 10.1002/adsc.201900864 ; Оаe C. Химия органических соединений серы : пер. с япон. ; под ред. Е.Н. Прилежаевой. Москва : Химия, 1975. 512 с. ; Бартон Д., Оллис У.Д. Общая органическая химия ; ред. Н.К. Кочетков. Москва : Химия, 1983. Том 5: Соединения фосфора и серы. 720 с. ; Лубенець B.I. Тіосульфонати: синтез $і$ властивості. Укр. хім. ж. 2003. Т. 69 (8). C. 114-122. ; Естери тіосульфокислот: одержання, властивості та перспективи застосування / Н.Я. Монька та ін. Укр. хім. ж. 2018. Т. 84. № (9/10). С. 65-97. URL: https://ucj.org.ua/index.php/journal/issue/view/9/10-2018 (дата звернення: 02.03.2020). Synthesis and study of pesticidal activity of some $\mathrm{N}$-arylthio-1,4-benzoquinone imines / L. Kuzmenko et al. Biointerface Research in Applied Chemistry. 2019. Vol. 9. Iss. 5. 4232-4238.

${ }^{2}$ P. Mampuys. Opus citato. Adv. Synth. Catal., 2020. 362. 3-64.

(March 15th 2019). Thiosulfonates: The Prospective Substances against Fungal Infections. In: Fungal Infection / V. Lubenets et al. ; Eds. Érico Silva de Loreto and Juliana Simoni Moraes Tondolo, IntechOpen, London. DOI: 10.5772/intechopen.84436 ; Synthesis and antimicrobial properties of 4-acylaminobenzenethiosulfoacid S-esters / V. Lubenets et al. Saudi Pharmaceutical Journal. 2017. Vol. 25 (2). 266-274. DOI: http://dx.doi.org/10.1016/j.jsps.2016.06.007

Лубенеиь B.I. Opus citato. Укр. хім. ж. 2003. T. 69 (8). С. 114-122.
} 
Перерозподіл електронної густини та зміна реакційної здатності в біохімічних реакціях надає сполукам цього класу можливість використання їх як високоефективних біологічно активних субстанцій ${ }^{5}$, а саме інсектицидів ${ }^{6}$, засобів захисту рослин та рістрегуляторів ${ }^{7}$, консервантів фруктів і овочів ${ }^{8}$, біоцидів для захисту матеріалів і виробів 3 них від біоуражень ${ }^{9}$, а також можливість використання як субстанції фармакологічних засобів, зокрема для лікування піроплазмоза (бабезіоза), як ефективних інгібіторів аномальної декструкції еритроцитів ${ }^{10}$, як антигельмінтних препаратів ${ }^{11}$. Конкурентоспроможність S-естерів тіосульфокислот як високоефективних субстанцій лікарських засобів ілюструють дані щодо терапії грибкових шкірних уражень, зокрема лікування епідермофітії стоп етилтіосульфанілатом у формі 1\% мазі,

${ }^{5}$ Synthesis and anti-platelet activity of thiosulfonate derivatives containing a quinone moiety / Kh. Bolibrukh et al. Scientia Pharmaceutica. 2015. Vol. 83. 221-231. URL: https://www.researchgate.net/publication/281438155; Aktywnosc przeciwgrzybicza syntetycznych pochodnych allicyny - kontynuacja badan / Urzula Nawrot et al. Mikologia Lekarska. 2012. Vol. 4. № 19. 143-146. URL: http://cornetis.pl/artykul/5853.html ; The search of compounds with antiaggregation activity among S-esters of thiosulfonic acids. / T.I. Halenova et al. Ukr. Biochem. J. 2015.87 (5). 83-92. DOI: https://doi.org/10.15407/ubj87.05.083 ; 12. Synthesis of new thiosulfonate derivatives with quinone and quinoxaline fragments / Kh. Bolibrukh et al. Chemical Technology. 2013. Vol. 63. 14-20.; The importance of rhamnolipid- biosurfactant induced changes in bacterial membrane lipids of Bacillus subtilis for the antimicrobial activity of thiosulfonates / Anna Sotirova et al. Curr. Microbiol. 2012. Vol. 65 (5). 534-541. URL: http://link.springer.com/article/10.1007/s00284-012-0191-7 ; Монька Н.Я. Opus citato. Укр. хім.ж. 2018. Т. 84 № 9/10. С. 65-97 ; Lubenets V. Opus citato. DOI:10.5772/intechopen.84436 ; Lubenets V. Opus citato. Saudi Pharmaceutical Journal. 2017. Vol. 25 (2). 266-274.

6 Svnthesis Method for Thiosulfonate and Report of Its Insecticidal Activity in Anagasta kuehniella (Lepidoptera Pvralidae) / E. Santos et al. Int. J. Mol. Sci. 2012. Vol. 13. 15241-15251. DOI: 10.3390/ijms131115241

15. Modification of Alkyl Esters of 4-Aminobenzenethiosulfonic Acid by sTriazine Fragment and Investigation of their Growth-Regulative Activity / S. Vasylyuk et al. Chem. \& Chem. Technol. 2018. Vol. 12. № 1. 24-28. URL: https://doi.org/10.23939/chcht12.01.024; 16.Influence of surfaceactive rhamnolipid biocomplex and ethylthiosulfanilate on growth and biochemical parameters of plants in oil contaminated soil / A.R. Banya et al. Biotechnologia Acta. 2015. 8 (5). 71-77. DOI: $10.15407 /$ biotech8.05.071

${ }_{9}^{8}$ Lubenets V. Opus citato. DOI:10.5772/intechopen.84436

9 Нові технології ефективного захисту текстилю від мікробіологічних пошкоджень / І.А. Мартиросян та ін. Наносистеми, наноматеріали, нанотехнології. Щоквартальний збірник наукових праиь. Київ : РВВ ІМФ, 2019. Т. 17. № (4). C. 621-636. PACS numbers: 81.05.Lg, 81.16.Fg, 83.80.Mc, 87.85.jf, 87.85.Rs, 87.85.M

${ }^{10}$ Патент 2573077 Франція : МКИ С 07 D 235/28, A 61 K 31/47. Nouveaux derives thiosulfonates, leur procede de preparation ainsi que les compositions pharmaceutiques les contenant / Sebille Bernard, Beuzard Yves, Demarne Henri (Франція). № 8417286 ; заявлен. 13.11.84 ; опубл. 16.05.86, РЖХ. 9О138П.

${ }_{11}$ The S-methyl-(2-methoxycarbonylaminobenzoimidasole-5) thiosulfonate as potential antiparasitic agent - action on development of Ascaris suum eggs in vitro / M. Dmitryjuk et al. Annals of Parasitology. 2019. Vol. 65. supplement 1: Abstracts of the XXV Congress of the Polish Parasitological Society, Warsaw, 9-12 September 2019, 155-156. 
лікувальний ефект якої за рахунок кератолітичних властивостей перевищує ринкові/промислові аналоги за дією ${ }^{12}$.

Перспективним у теоретичному i практичному аспектах $\epsilon$ дослідження синтезу та властивостей функціоналізованих S-естерів тіосульфокислот для встановлення взаємозв'язку особливостей їхньої будови 3 реакційною здатністю, стабільністю та біологічною активністю, що дозволяє визначити стратегію цілеспрямованого синтезу сполук цього класу 3 комплексом практично цінних властивостей.

Сьогодні відомі різні альтернативні шляхи синтезу S-естерів тіосульфокислот (представлені загальною схемою (рис. 1)), кожен 3 яких не позбавлений недоліків.

\begin{tabular}{|c|c|c|c|}
\hline $\begin{array}{l}\text { овиснення меркаптанів } \\
\text { та дисульфітів } \\
\mathrm{RSH}+\mathrm{AlkONO} \\
\mathrm{RSSR}^{1+} \mathrm{O}_{2} \\
\mathrm{RSSR}^{1}+2 \mathrm{Cl}_{2}\left(\mathrm{H}_{2} \mathrm{O}\right) \\
\mathrm{RSSR}^{1}+\mathrm{H}_{2} \mathrm{O}_{2} \text { (AcOH) } \\
\mathrm{RSSR}^{1}+\mathrm{M}_{2} \mathrm{O}_{2} \\
\mathrm{RSSR}^{1}+\mathrm{NO}_{2} \\
\mathrm{RSSR}^{1}+\mathrm{SO}_{2} \mathrm{Cl}_{2}(\mathrm{AcOH}) \\
\mathrm{RSSR}^{1}+\mathrm{NaJO}_{4} \\
\mathrm{RSSR}^{1}+\mathrm{RCO}_{3} \mathrm{H} \\
\mathrm{RSSR}^{1}+\mathrm{Cr}_{2} \mathrm{O}_{3} \\
\mathrm{RSSR}^{1}+\mathrm{K}_{2} \mathrm{Cr}_{2} \mathrm{O}_{7}\end{array}$ & $\begin{array}{l}\text { симтези д } \\
\text { тіосупьф } \\
\mathrm{RSO}_{2} \mathrm{SH} \\
\mathrm{RSO}_{2} \mathrm{SH} \\
\mathrm{RSO}_{2} \mathrm{SH}\end{array}$ & $\begin{array}{l}\text { Moni } \\
\text { not } \\
\mathrm{C}(=0) \mathrm{H} \\
\mathrm{OCN} \\
\mathrm{I}_{2}=\mathrm{CHR}^{1}\end{array}$ & 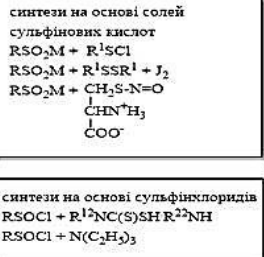 \\
\hline 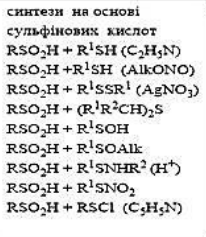 & $\begin{array}{l}\text { сиятели иа основі естерів } \\
\text { тіосульфінових кислот } \\
\mathrm{RS}(=0) \mathrm{SR}^{1}+\mathrm{H}^{+} \text {диспр } \\
\mathrm{RS}(=0) \mathrm{SR}^{1}+\mathrm{O}_{2} \\
\mathrm{RS}(=0) \mathrm{SR}^{1}+\mathrm{NaJO}_{4} \\
\mathrm{RS}(=0) \mathrm{SR}^{1}+\mathrm{H}_{2} \mathrm{O}_{2} \\
\mathrm{RS}(=0) \mathrm{SR}^{1}+\mathrm{RCO}_{3} \mathrm{H}\end{array}$ & $\begin{array}{l}\text { синтези на основі солей } \\
\text { тіосульвонистот } \\
\mathrm{RSO}_{2} \mathrm{SM}+\mathrm{R}^{1} \mathrm{Hal} \\
\mathrm{RSO}_{2} \mathrm{SM}+\left(\mathrm{Alk}_{2}\right)_{2} \mathrm{SO}_{4} \\
\mathrm{RSO}_{2} \mathrm{SM}+\mathrm{Ar}_{2}^{1} \mathrm{~N}_{2}^{+} \mathrm{Cl}- \\
\mathrm{RSO}_{2} \mathrm{SM}+\mathrm{R}^{1} \mathrm{SO}_{2} \mathrm{SAlk} \\
\mathrm{RSO}_{2} \mathrm{SM}+\mathrm{H}_{2} \mathrm{C}-\mathrm{CH}_{2} \\
\mathrm{~S}_{2}^{\prime}\end{array}$ & $\begin{array}{l}\text { сиятези на основі } \\
\text { похідияк сульфокислот } \\
\mathrm{RSO}_{2} \mathrm{Hal}+\mathrm{Zn}+\mathrm{HCl} \\
\mathrm{RSO}_{2} \mathrm{Hal}+\mathrm{KJ} \text { (адетон, пірідін) } \\
\mathrm{RSO}_{2} \mathrm{Hal}+\left(\mathrm{H}_{2}\right) \\
\mathrm{RSO}_{2} \mathrm{Hal}+\mathrm{R}^{1} \mathrm{SH} \\
\mathrm{RSO}_{2} \mathrm{Hal}+\mathrm{R}^{1} \mathrm{SHgR}^{2} \\
\mathrm{RSO}_{2} \mathrm{Hal}+\mathrm{Hg}^{2}\left(\mathrm{SCF}_{3}\right)_{2} \\
\left(\mathrm{RSO}_{2}\right)_{2} \mathrm{O}+\mathrm{R}^{1} \mathrm{SH}\end{array}$ \\
\hline
\end{tabular}

\section{Рис. 1. Шляхи синтезу S-естерів тіосульфокислот}

Основною проблемою синтезу S-естерів тіосульфокислот $\epsilon$ те, що серед великої різноманітності відомих методів отримання сполук цього класу синтез структур певної будови можна здійснити лише використанням визначених конкретних методів, що створює необхідність пошуку різних альтернативних шляхів та розроблення нових методів синтезу.

12 Ethylthiosulfanilate effect on Candida tropicalis / L.B. Oriabinska et al. Ukr.Biochem.J. 2017. № 89 (5). C. 70-76. DOI: https://doi.org/10.15407/ubj89.05.070 ; Development of new antimicrobial compositions of thiosulfonate structure / V. Lubenets et al. Chemistry \& Chemical technology. 2013. Vol. 7. № 2. P. 119-124. URL: http://old.lp.edu.ua/fileadmin/ICCT/journal/Vol.7/No_2/01.pdf ; Effects of thiosulfonates on the lipid composition of rat tissues / A.Z. Pylypets et al. Ukr.Biochem.J. 2017. № 89 (6). C. 58-64. DOI: https://doi.org/10.15407/ubj89.06.056 


\section{1. Синтез S-естерів тіосульфокислот \\ із 3,4-дизаміщеними арильними фрагментами \\ в сульфонільному або тіольному складниках}

Одним із перспективних напрямів пошуку нових ефективних та малотоксичних біологічно активних сполук $є$ синтез тіосульфоестерів 3 функціональними групами в замісниках зі сторони сульфуру різних ступенів окиснення. Введення функціональних замісників, зокрема фармакофорних, дозволяє не лише цілеспрямовано змінювати фізикохімічні властивості тіосульфоестерів, але й відкриває нові шляхи їх потенційного використання в подальших хімічних перетвореннях унаслідок зміни реакційної здатності тіосульфонатної групи або інших функціональних груп зі збереженням фармакофорної тіосульфогрупи.

Природа, кількість і положення замісників арилсульфонільного фрагмента тіосульфоестерів суттєво впливає на стабільність ${ }^{13}$ та біологічну активність ${ }^{14}$, що яскраво ілюструє вплив уведення аміноабо ацетиламіногрупи в пара-положення алкілових $\mathrm{S}$-естерів бензентіосульфокислоти на спектр їхньої антимікробної дії ${ }^{15}$.

Введенням 3,4-дизаміщених арильних фрагментів у сульфонільну або тіольну частину структури S-естерів тіосульфокислот здійснено цілеспрямований синтез низки сполук, структура яких представлена на рис. 2.

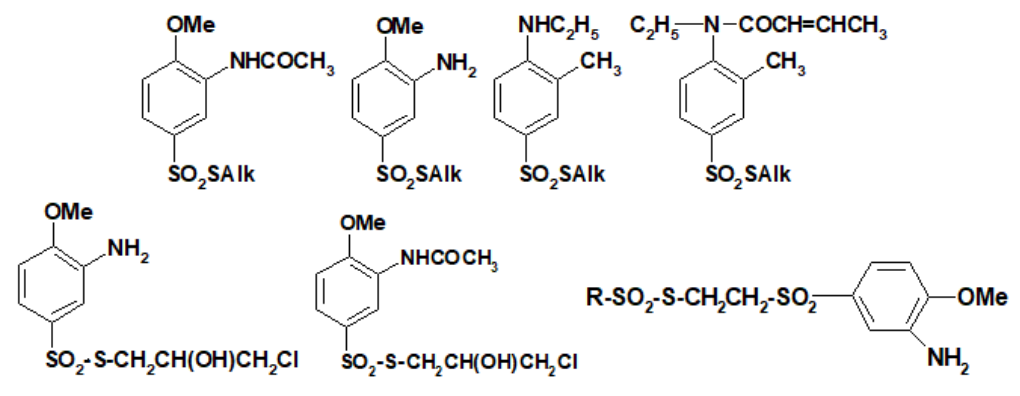

\section{Рис. 2. S-алкілові та S-алкілфункціоналізовані естери 3,4-дизаміщених арилтіосульфокислот}

\footnotetext{
${ }^{13}$ Баранович Д.Б., Лубенець В.І., Новіков В.П. Синтез S-алкіл 3,4-дизаміщених бензолтіосульфонатів і їх взаємодія з гідроксидом амонію. Укр. хім. журн. 1999. Т. 65 (12). С. 130-136. ; Лубенець В.І., Баранович Д.Б., Новіков В.П. Тіосульфонати на основі оксифенілпохідних. Укр. хім. журн. 2001. № 67 (1). С. 45-48.

${ }_{14}$ Патент на корисну модель № 64412. Застосування S-метил-4амінобензентіосульфонату як біоциду для захисту фарб та грунтовок / B.I. Лубенець та ін. u 201103717 ; заявл. 28.03.2011; опубл. 10.11.2011, Бюл. № 21. ; Lubenets V. Opus citato. Saudi Pharmaceutical Journal. 2017. Vol. 25 (2). 266-274.

15 Лубенець B.I. Opus citato. Укр. хім. журн. 2001. № 67 (1). C. 45-48. ; Lubenets V. Opus citato. Saudi Pharmaceutical Journal. 2017. Vol. 25 (2). 266-274.
} 
Алкілові S-естери 3-аміно-4-метоксибензентіосульфокислот 4.1-4.3 отримано двома альтернативними шляхами (рис. 3): класичною схемою синтезу взаємодією солей лужних металів тіосульфокислот 3 відповідними алкілюючими реагентами ${ }^{16}$ або кислотним гідролізом естерів 2.1-2.4 сульфатною або хлоридною кислотами.

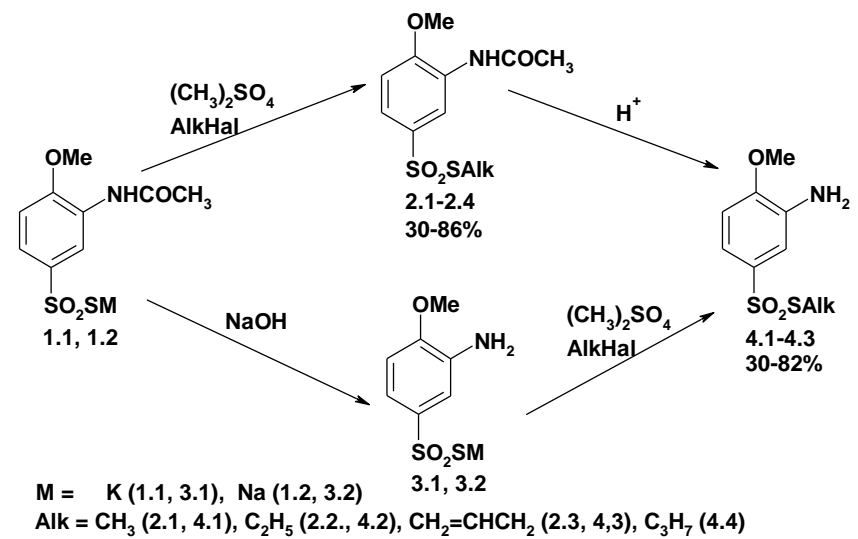

\section{Рис. 3. Синтез алкілових S-естерів 3-ацетиламіно-4-метоксибензен- та 3-аміно-4-метоксибензентіосульфокислоти}

Вихідні калієві та натрієві солі 3-ацетиламіно-4метоксибензенсульфохлориду $1.1,1.2$ отримані окисно-відновною взаємодією 3-ацетиламіно-4-метоксибензенсульфохлориду 3 насиченим водним розчином гідросульфіду калію або водним розчином сульфіду натрію. Вихідний 3-ацетиламіно-4-метоксибензенсульфохлорид синтезовано сульфохлоруванням промислового $о$-ацетиламіноанізолу. Запропоновано оптимальні умови синтезу алкілових естерів 3,4дизаміщених тіосульфокислот 2.1-2.4 та 4.1-4.3 як результат дослідження впливу реакційної здатності реагентів, природи розчинника, температури та тривалості реакції алкілювання (табл. 1$)^{17}$. Найбільший вихід метилових та алілових S-естерів отримано за $20^{\circ} \mathrm{C}$ у водному ацетоні $(\eta=82 \%)$, етилових та пропілового естерів $-3 a 45^{\circ} \mathrm{C}$ у метанолі $(\eta=68 \%)$. Деацилювання аміногрупи можна здійснити на стадіях отримання солей 3.1, 3.2 або цільових тіосульфоестерів 4.1-4.3, що дозволяє запропонувати альтернативні шляхи синтезу iз задовільними виходами.

16 Синтез и противомикробная активность эфиров 3,4-дизамещенных бензолтиосульфокислот / В.И. Лубенец и др. Химико-фарм. журнал. 2000. № 34 (3). C. $15-18$.

${ }^{17}$ Баранович Д.Б. Opus citato. Укр. хім. журн. 1999. Т. 65 (12). С. 130-136. 
Таблиця 1

Залежність виходу S-алкіл-3-ацетиламіно-4-метокси- 2.1-2.4, S-алкіл-3-аміно-4-метоксибензентіосульфонатів 4.1-4 від умов алкілювання

\begin{tabular}{|c|c|c|c|c|c|c|}
\hline \multirow[b]{2}{*}{ № } & \multicolumn{2}{|c|}{ Вихідні речовини } & \multirow[b]{2}{*}{$\begin{array}{c}\text { Розчинник } \\
\text { (співідношення) }\end{array}$} & \multirow[b]{2}{*}{$\mathbf{T},{ }^{\circ} \mathbf{C}$} & \multirow[b]{2}{*}{$\begin{array}{l}\text { Час, } \\
\text { год }\end{array}$} & \multirow[b]{2}{*}{$\underset{\%}{\text { Вихід, }}$} \\
\hline & $\mathrm{RSO}_{2} \mathrm{SM}$ & $\begin{array}{c}\text { алкілуючий } \\
\text { реагент }\end{array}$ & & & & \\
\hline \multirow{5}{*}{2.1} & \multirow{5}{*}{1.1} & \multirow{5}{*}{$\left(\mathrm{CH}_{3}\right)_{2} \mathrm{SO}_{4}$} & ацетон:вода 10:1 & 20 & 0.5 & 82 \\
\hline & & & ацетон:вода 5:1 & 20 & 2 & 78 \\
\hline & & & ацетон:вода 1:1 & 20 & 2 & 66 \\
\hline & & & вода & 20 & 2 & 50 \\
\hline & & & метанол & 45 & 1 & 81 \\
\hline \multirow{6}{*}{2.2} & \multirow{6}{*}{1.2} & \multirow{6}{*}{$\mathrm{C}_{2} \mathrm{H}_{5} \mathrm{Br}$} & ацетон:вода 10:1 & 20 & 48 & 66 \\
\hline & & & метанол & 45 & 6 & 68 \\
\hline & & & етанол & 40 & 6 & 54 \\
\hline & & & етанол & 60 & 6 & 63 \\
\hline & & & ДМФА & 20 & 24 & 64 \\
\hline & & & ДМФА & 80 & 6 & 63 \\
\hline \multirow{6}{*}{2.3} & \multirow{6}{*}{1.1} & \multirow{6}{*}{$\mathrm{CH}_{2}=\mathrm{CH}-\mathrm{CH}_{2} \mathrm{Br}$} & ацетон:вода 10:1 & 20 & 2 & 64 \\
\hline & & & ацетон:вода 1:1 & 20 & 24 & 24 \\
\hline & & & метанол & 45 & 6 & 48 \\
\hline & & & хлороформ & 40 & 6 & 42 \\
\hline & & & ДМФА & 20 & 6 & 57 \\
\hline & & & ДМФА & 80 & 6 & 69 \\
\hline \multirow{4}{*}{2.4} & \multirow{4}{*}{1.2} & \multirow{4}{*}{$\mathrm{C}_{3} \mathrm{H}_{7} \mathrm{Br}$} & ацетон:вода 10:1 & 20 & 144 & 30 \\
\hline & & & ацетон:вода 5:1 & 20 & 120 & 17 \\
\hline & & & метанол & 45 & 10 & 38 \\
\hline & & & ДМФА & 80 & 8 & 28 \\
\hline \multirow{4}{*}{4.1} & \multirow{4}{*}{3.1} & \multirow{4}{*}{$\left(\mathrm{CH}_{3}\right)_{2} \mathrm{SO}_{4}$} & ацетон:вода 10:1 & 20 & 2 & 35 \\
\hline & & & ацетон:вода1:1 & 20 & 2 & 33 \\
\hline & & & вода & 20 & 2 & 18 \\
\hline & & & метанол & 45 & 1 & 33 \\
\hline \multirow{4}{*}{4.2} & \multirow{4}{*}{3.1} & \multirow{4}{*}{$\mathrm{C}_{2} \mathrm{H}_{5} \mathrm{Br}$} & ацетон:вода 10:1 & 20 & 48 & 40 \\
\hline & & & ацетон:вода 1:1 & 20 & 96 & 35 \\
\hline & & & метанол & 45 & 6 & 44 \\
\hline & & & ДМФА & 80 & 6 & 37 \\
\hline \multirow{5}{*}{4.3} & \multirow{5}{*}{3.2} & \multirow{5}{*}{$\mathrm{CH}_{2}=\mathrm{CH}-\mathrm{CH}_{2} \mathrm{Br}$} & ацетон:вода 10:1 & 20 & 2 & 30 \\
\hline & & & хлороформ & 40 & 8 & 25 \\
\hline & & & метанол & 45 & 6 & 27 \\
\hline & & & ДМФА & 20 & 6 & 28 \\
\hline & & & ДМФА & 80 & 6 & 31 \\
\hline
\end{tabular}

S-метил-3-метил-4-етиламінобензентіосульфонат $\mathbf{5 . 1} \quad(\eta=65 \%)$ та $\mathrm{S}$-метил- i S-аліл-3-метил-4-(N-етил-N-кротил)амінобензентіо-сульфонати 6.1, 6.2 (відповідно, $\eta=58 \%$ і $\eta=62 \%$ ) синтезовано згідно з рис. 4 . 


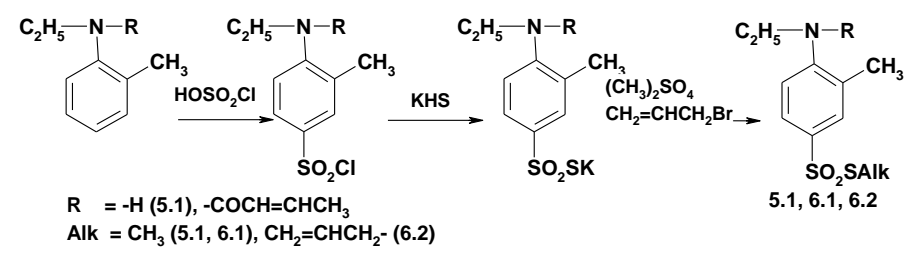

Рис. 4. Синтез S-естерів 3-метил-4-етиламінобензен-5.1, 4-(N-етил-N-кротил)амінобензентіосульфокислот 6.1, 6.2

Крім широко застосовуваних алкілгалогенідів, як алкілюючі агенти використано оксирани, алкілювання якими солей лужних металів тіосульфокислот у присутності як каталізатора кислот Льюїса $\left(\mathrm{ZnCl}_{2}, \quad \mathrm{BF}_{3} \cdot\left(\mathrm{C}_{2} \mathrm{H}_{5}\right)_{2} \mathrm{O}\right)$ отримано $\mathrm{S}$-( $\beta$-гідроксиалкіл)тіосульфонати ${ }^{18}$. Даним шляхом синтезовано S-(3-хлоро-2-гідроксипропіл)-3-метокси4-ацетиламінобензентіосульфонат 7.1 (74\%).

Запропоновано використання натрієвої солі 3-аміно4-метоксибензенсульфонілетилсульфокислоти 8.1 як алкілюючого агента солей тіосульфокислот з утворенням етилзаміщених естерів 9.1-9.8 (рис. 5) та запропонована препаративна методика їхнього синтезу як результат досліджень умов конденсації: розчинники $-\mathrm{H}_{2} \mathrm{O}$, ацетон:вода, водний етанол, ДМФА; температурний режим у межах $40 \ldots 100^{\circ} \mathrm{C}$; різна тривалість конверсії (табл. 2$)^{19}$.

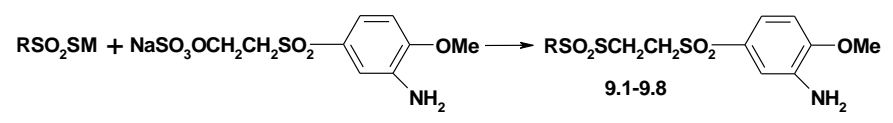
Рис. 5. Синтез S-[2-(3-аміно-4-метоксибензенсульфоніл)- етил|тіосульфонатів 9.1-9.8

\footnotetext{
${ }^{18}$ Baranovich D.B.. Lubenets V.I.. Novikov V.P. Svnthesis of Thiosulfonates with Functional Groups in the Aliphatic Chain. Russian Journal of Organic Chemistry. 2001. Vol. 37. № 7. C. 1046-1047. Translated from Zhurnal Organicheskoi Khimii. 2001. Vol. 37. № 7. C. 1093-1094. URL: https://doi.org/10.1023/A:1012499121615

Baranovich D.B., Lubenets V.I., Novikov V.P. Synthesis of S-[2-(4Aminobenzenesulfonyl)ethyl] and S-[2-(3-Amino-4-methoxybenzenesulfonyl)ethyl] Thiosulfonates. Russian Journal of General Chemistry. 2001. Vol. 71. № 11. C. 1827. Translated from Zhurnal Obshchei Khimii. 2001. Vol. 71. № 11. C. 1932. URL: https://doi.org/10.1023/A:1013987618313;29. Синте3 S-[2-(арилсульфоніл)етил] тіосульфонатів та їх гідроліз / В.І. Лубенець та ін. Укр. хім. журн. 2001. № 67 (12). C. 103-109; 30. Патент на винахід UA 63685 А. Україна. МПК 7 С07C381/00, C07C381/04. Заміщені арилсульфонілетилові S-естери тіосульфокислот, спосіб їх отримання, алкілуючі реагенти солей тіосульфокислот / B.I. Лубенець B.I. та ін. № 2003054921 ; заявл. 29.05.2003 ; опубл. 15.01.2004, Бюл. № 1.
} 


\section{Таблиця 2}

Залежність виходу S-[2-(3-аміно-

4-метоксибензенсульфоніл)етил]тіосульфонатів 9.1-9.8

від умов конденсації

\begin{tabular}{|c|c|c|c|c|c|c|c|}
\hline \multirow{3}{*}{ № } & \multirow{2}{*}{\multicolumn{3}{|c|}{$\mathrm{R}^{1} \mathrm{OSO}_{3} \mathrm{Na}+\mathrm{RSO}_{2} \mathrm{SM} \rightarrow \mathrm{RSO}_{2} \mathrm{SR}^{1}$}} & \multirow{3}{*}{$\begin{array}{c}\text { Розчинник } \\
\text { співідношення }\end{array}$} & \multirow{3}{*}{$\begin{array}{l}\mathbf{T}, \\
{ }^{\circ} \mathbf{C}\end{array}$} & \multirow{3}{*}{$\begin{array}{l}\text { Час, } \\
\text { год }\end{array}$} & \multirow{3}{*}{$\begin{array}{c}\text { Вихід, } \\
\%\end{array}$} \\
\hline & & & & & & & \\
\hline & $\mathbf{R}^{1}$ & $\mathbf{R}$ & $\mathbf{M}$ & & & & \\
\hline \multirow{14}{*}{9.1} & \multirow{27}{*}{$\mathrm{SO}_{2} \mathrm{CH}_{2} \mathrm{CH}_{2}-$} & \multirow{14}{*}{ 4- $\mathrm{NH}_{2} \mathrm{C}_{6} \mathrm{H}_{4}-$} & \multirow{14}{*}{$\mathrm{Na}$} & ацетон:вода 10:1 & 20 & 24 & 13 \\
\hline & & & & ацетон:вода 5:1 & 20 & 12 & 11 \\
\hline & & & & ацетон:вода 5:1 & 20 & 24 & 16 \\
\hline & & & & ацетон:вода 1:1 & 20 & 12 & 15 \\
\hline & & & & ацетон:вода 1:1 & 20 & 24 & 20 \\
\hline & & & & етанол:вода & 20 & 8 & 32 \\
\hline & & & & етанол:вода & 40 & 7 & 44 \\
\hline & & & & метанол & 64 & 6 & 39 \\
\hline & & & & ДМФА & 20 & 12 & 29 \\
\hline & & & & ДМФА & 80 & 6 & 46 \\
\hline & & & & вода & 100 & 6 & 70 \\
\hline & & & & вода & 80 & 4 & 63 \\
\hline & & & & вода & 80 & 7 & 71 \\
\hline & & & & вода & 40 & 24 & 51 \\
\hline \multirow{4}{*}{9.2} & & \multirow{4}{*}{$4-\mathrm{CH}_{3} \mathrm{CONHC}_{6} \mathrm{H}_{4-}$} & & вода & 100 & 6 & 72 \\
\hline & & & $\mathrm{Na}$ & вода & 80 & 6 & 70 \\
\hline & & & & вода & 75 & 7 & 66 \\
\hline & & & $\mathrm{K}$ & вода & 80 & 6 & 73 \\
\hline \multirow{3}{*}{9.3} & & \multirow{3}{*}{ 4- $\mathrm{CH}_{3} \mathrm{C}_{6} \mathrm{H}_{4-}^{-}$} & $\mathrm{Na}$ & етанол & 78 & 7 & 37 \\
\hline & & & $\mathrm{Na}$ & вода & 100 & 9 & 65 \\
\hline & & & $\mathrm{K}$ & вода & 100 & 8 & 68 \\
\hline 9.4 & & $\begin{array}{l}\text { 3- } \mathrm{CH}_{3} \mathrm{CONH}_{-} 4- \\
\mathrm{CH}_{3} \mathrm{OC}_{6} \mathrm{H}_{3} 3^{-}\end{array}$ & $\mathrm{K}$ & вода & 100 & 1 & 66 \\
\hline 9.5 & & $\mathrm{C}_{6} \mathrm{H}_{5^{-}}$ & $\mathrm{K}$ & $\begin{array}{l}\text { вода } \\
\text { вода }\end{array}$ & $\begin{array}{l}100 \\
80\end{array}$ & $\begin{array}{l}2 \\
6\end{array}$ & $\begin{array}{l}33 \\
48\end{array}$ \\
\hline 9.6 & & $4-\mathrm{ClC}_{6} \mathrm{H}_{4^{-}}$ & $\mathrm{K}$ & вода & 80 & 3.5 & 56 \\
\hline 9.7 & & $\mathrm{CH}_{3-}^{-}$ & $\mathrm{K}$ & вода & 80 & 5 & 48 \\
\hline \multirow{2}{*}{9.8} & & \multirow{2}{*}{$\mathrm{C}_{2} \mathrm{H}_{5^{-}}$} & \multirow[t]{2}{*}{$\mathrm{K}$} & вода & 100 & 6 & 44 \\
\hline & & & & вода & 80 & 8 & 43 \\
\hline
\end{tabular}

Фізико-хімічні характеристики описаних S-естерів тіосульфокислот 3 3,4-дизаміщеними арильними фрагментами в сульфонільному або тіольному складниках представлено в низці опублікованих статей ${ }^{20}$.

${ }^{20}$ Лубенец В.И. Opus citato. Химико-фарм. журнал. 2000. № 34 (3). № 15-18 ; Baranovich D.B. Opus citato. Russian Journal of Organic Chemistry. 2001. Vol. 37. № 7. C. 1046-1047. ; Baranovich D.B. Opus citato. Russian Journal of General Chemistry. 2001. Vol. 71. № 11. С. 1827.; Лубенець B.I. Opus citato. Укр. хім. журн. 2001. № 67 (12). № 103-109. 


\section{2. Стабільність S-естерів тіосульфокислот із 3,4-дизаміщеними арильними фрагментами сульфонільного або тіольного складників}

\section{в умовах лужного гідролізу}

$\mathrm{S}$-естери тіосульфокислот - синтетично цінні реагенти, стабільніші, ніж сульфенілгалогеніди. Серед взаємодій S-естерів, які відбуваються за гетерогенним механізмом, за кількістю досліджень виділяють реакції 3 нуклеофільними реагентами, які можуть бути моделями сульфенілювання нуклеофільних центрів біологічних об'єктів у системах, близьких до природних. Тому в низці реакцій 3 нуклеофільними реагентами важливим $\epsilon$ лужний гідроліз, який ілюструє стабільність S-естерів тіосульфокислот та визначає область їх можливого застосування залежно від $\mathrm{pH}$ середовища.

Багатостадійний механізм лужного гідролізу можна розглядати як сумарне рівняння бімолекулярного процесу, кінцевими продуктами якого $є$ у співвідношенні 1:3:1 дисульфід та дві сульфінові кислоти, які в умовах взаємодії перетворюються у відповідні сульфінати ${ }^{21}$.

\section{$3 \mathrm{RSO}_{2 \mathrm{SR} 1}+4 \mathrm{HO}^{-} \longrightarrow \mathrm{R}^{-} \mathrm{SSR} 1+3 \mathrm{RSO}^{-}+\mathrm{R}^{-} \mathrm{SO}^{-}+2 \mathrm{H} 2 \mathrm{O}$}

Розраховані ефективні константи другого порядку за формальним підходом до кінетики лужного гідролізу тіосульфоестерів ${ }^{22}$.

Основним критерієм стабільності S-[2-(3-аміно-4метоксибензенсульфоніл)етил]етантіосульфонату в умовах лужного гідроліза $\epsilon$ наявність аліфатичного або ароматичного фрагмента в кислотному складнику. Встановлено, що константа швидкості гідролізу для S-[2-(3-аміно-4-метоксибензенсульфоніл)етил]етан-тіосульфонату 9.8 в 4 рази менша за константу аналогічного естеру бензентіосульфокислоти 9.5 та в 9-10 разів менша за константи аналогічних естерів заміщених арилтіосульфокислот ${ }^{23}$. За результатами кінетичних досліджень S-[2-(3-аміно4-метоксибензенсульфоніл)етил]тіо-сульфонати відповідно до їхньої стабільності в умовах лужного гідролізу розташовані в ряд:

\section{4- $\mathrm{CH}_{3} \mathrm{CONHC}_{6} \mathrm{H}_{4^{-}}>\mathrm{C}_{6} \mathrm{H}_{5^{-}}>3-\mathrm{CH}_{3} \mathrm{CONH}-4-\mathrm{CH}_{3} \mathrm{OC}_{6} \mathrm{H}_{3^{-}}$}

Константа швидкості гідролізу S-(2-гідрокси-3-хлоропропіл)3-ацетиламіно-4-метоксибензентіосульфонату 7.1 на порядок вища за константу швидкості пропілового естеру аналогічної тіосульфокислоти за рахунок -I ефекту функціональних груп алкільного тіольного фрагменту. Швидкість гідролізу

${ }^{21}$ Лубенеиь B.I. Opus citato. Укр. хім. ж. 2003. T. 69 (8). С. 114-122.

22 Баранович Д.Б. Opus citato. Укр. хім. журн. 1999. Т. 65 (12). С. 130-136.

${ }^{23}$ Баранович Д.Б. Opus citato. Укр. хім. журн. 1999. Т. 65 (12). С. 130-136. 
S-аліл-3-ацетиламіно-4-метоксибензентіосульфонату 2.3 майже вдвічі більша за конвессію пропілового S-естера аналогічної тіосульфокислоти 2.4 внаслідок зменшення електронної густини на атомі тіольного сульфуру за рахунок -I ефекта алільного фрагмента.

Отже, швидкість конверсії S-естерів тіосульфокислот в умовах лужного гідролізу залежить від ступені дисоціації лужного агента та від реакційної здатності S-естерів унаслідок перерозподілу електронної густини на тіольному сульфурі за рахунок природи тіольного і сульфонільного фрагментів (табл. 3,4$)^{24}$.

Таблиця 3

Кінетичні характеристики лужного гідролізу S-естерів тіосульфокислот (лужний агент - NaOH)

\begin{tabular}{|c|c|c|c|c|c|c|c|c|c|}
\hline \multirow{2}{*}{ Естер } & Yac, & Конверсія, & $K_{1}$ & $K_{1}$ & \multirow{2}{*}{ Естер } & \multirow{2}{*}{$\begin{array}{c}\text { Yac, } \\
\text { XB }\end{array}$} & \multirow{2}{*}{$\begin{array}{c}\text { Конверсія, } \\
\%\end{array}$} & \multirow{2}{*}{\multicolumn{2}{|c|}{\begin{tabular}{|l|r}
$K_{1}$ & $K_{1}$ \\
л/моль'хв
\end{tabular}}} \\
\hline & $\mathbf{X B}$ & & $\pi / M C$ & $\mathrm{~b} \cdot \mathrm{XB}$ & & & & & \\
\hline 2.4 & $\begin{array}{c}5 \\
10 \\
20 \\
30 \\
60 \\
120 \\
\end{array}$ & $\begin{array}{c}6.60 \\
12.00 \\
19.65 \\
22.05 \\
25.20 \\
29.70\end{array}$ & $\begin{array}{c}0.91 \\
\pm 0.002\end{array}$ & $\begin{array}{c}0.12 \\
\pm 0.005\end{array}$ & 9.4 & $\begin{array}{c}5 \\
10 \\
20 \\
40\end{array}$ & $\begin{array}{l}47.40 \\
72.45 \\
82.50 \\
99.90\end{array}$ & $\begin{array}{c}14.16 \\
\pm 0.298\end{array}$ & $\begin{array}{c}3.35 \\
\pm 0.14\end{array}$ \\
\hline 9.2 & $\begin{array}{c}5 \\
10 \\
20 \\
30\end{array}$ & $\begin{array}{l}63.90 \\
77.70 \\
86.85 \\
91.50\end{array}$ & $\begin{array}{r}15.25 \\
\pm 0.41\end{array}$ & $\begin{array}{c}6.13 \\
\pm 0.018\end{array}$ & 9.5 & $\begin{array}{c}5 \\
10 \\
20 \\
30 \\
60 \\
120 \\
\end{array}$ & $\begin{array}{l}36.90 \\
57.60 \\
71.55 \\
73.80 \\
80.25 \\
87.60\end{array}$ & $\begin{array}{c}6.27 \\
\pm 0.18\end{array}$ & $\begin{array}{c}1.00 \\
\pm 0.056\end{array}$ \\
\hline 9.3 & $\begin{array}{c}5 \\
10 \\
20 \\
30 \\
60\end{array}$ & $\begin{array}{l}34.05 \\
75.00 \\
79.50 \\
88.50 \\
90.90\end{array}$ & $\begin{array}{r}14.19 \\
\pm 1.02\end{array}$ & $\begin{array}{c}2.70 \\
\pm 0.002\end{array}$ & 9.8 & $\begin{array}{c}5 \\
10 \\
20 \\
30 \\
60 \\
120\end{array}$ & $\begin{array}{c}2.25 \\
27.30 \\
31.80 \\
38.70 \\
40.95 \\
45.45\end{array}$ & $\begin{array}{c}1.57 \\
\pm 0.19\end{array}$ & $\begin{array}{c}0.13 \\
+0.0001\end{array}$ \\
\hline
\end{tabular}

Таблиця 4

Кінетичні характеристики лужного гідролізу S-естерів тіосульфокислот (лужний агент $-\mathrm{NH}_{4} \mathrm{OH}$ )

\begin{tabular}{|c|c|c|c|c|c|c|c|c|c|}
\hline \multirow{2}{*}{ Естер } & Чac, & Конверсія, & $\mathbf{K}_{1}$ & $\mathbf{K}_{1}$ & \multirow{2}{*}{ Естер } & \multirow{2}{*}{$\begin{array}{l}\text { Чac, } \\
\text { XB }\end{array}$} & \multirow{2}{*}{$\begin{array}{c}\text { Конверсія, } \\
\%\end{array}$} & \multirow{2}{*}{\multicolumn{2}{|c|}{\begin{tabular}{|l|r}
$K_{1}$ & $K_{1}$ \\
л/моль·Хв
\end{tabular}}} \\
\hline & XB & & $\pi / \mathbf{M O}$ & $\mathrm{b} \cdot \mathrm{XB}$ & & & & & \\
\hline 2.1 & $\begin{array}{c}5 \\
10 \\
20 \\
30 \\
60 \\
120 \\
180\end{array}$ & $\begin{array}{l}18.15 \\
27.30 \\
45.45 \\
47.70 \\
54.60 \\
68.25 \\
77.25\end{array}$ & $\begin{array}{c}2.37 \\
\pm 0.107\end{array}$ & $\begin{array}{c}0.52 \\
\pm 0.015\end{array}$ & 7.1 & $\begin{array}{c}5 \\
10 \\
20 \\
30 \\
60 \\
120 \\
180\end{array}$ & $\begin{array}{l}20.40 \\
34.05 \\
37.05 \\
38.70 \\
49.95 \\
75.00 \\
90.90\end{array}$ & $\begin{array}{c}3.79 \\
\pm 0.004\end{array}$ & $\begin{array}{c}1.40 \\
\pm 0.067\end{array}$ \\
\hline 2.2 & $\begin{array}{c}5 \\
10 \\
20 \\
30 \\
60 \\
120\end{array}$ & $\begin{array}{l}12.75 \\
20.70 \\
28.50 \\
33.60 \\
43.20 \\
55.80\end{array}$ & $\begin{array}{c}2.09 \\
\pm 0.01\end{array}$ & $\begin{array}{c}0.52 \\
\pm 0.003\end{array}$ & 9.2 & $\begin{array}{c}5 \\
10 \\
20 \\
30 \\
60 \\
120 \\
180 \\
240 \\
\end{array}$ & $\begin{array}{c}0 \\
9.15 \\
13.65 \\
22.80 \\
31.80 \\
36.30 \\
45.45 \\
49.95 \\
\end{array}$ & $\begin{array}{c}0.72 \\
\pm 0.014\end{array}$ & $\begin{array}{c}0.2 \\
\pm 0.004\end{array}$ \\
\hline
\end{tabular}

${ }^{24}$ Баранович Д.Б. Opus citato. Укр. хім. журн. 1999. Т. 65 (12). С. 130-136. 
Продовження таблиці 4

\begin{tabular}{|c|c|c|c|c|c|c|c|c|c|}
\hline Естер & $\begin{array}{c}\text { Yac, } \\
\text { XB }\end{array}$ & $\begin{array}{c}\text { Конверсія, } \\
\%\end{array}$ & $K_{1}$ & $K_{1}$ & Естер & $\begin{array}{c}\text { Чac, } \\
\text { XB }\end{array}$ & $\begin{array}{c}\text { Конверсія, } \\
\%\end{array}$ & $\kappa_{1}$ & $K_{1}$ \\
\hline 2.3 & $\begin{array}{c}5 \\
10 \\
20 \\
30 \\
60 \\
120 \\
180\end{array}$ & $\begin{array}{l}12.90 \\
23.70 \\
38.70 \\
43.05 \\
51.60 \\
60.15 \\
62.40\end{array}$ & $\begin{array}{c}2.22 \\
+0.002\end{array}$ & $\begin{array}{c}0.33 \\
\pm 0.024\end{array}$ & 9.4 & $\begin{array}{c}5 \\
10 \\
20 \\
30 \\
60 \\
180\end{array}$ & $\begin{array}{c}0 \\
4.95 \\
19.95 \\
25.05 \\
30.00 \\
37.50\end{array}$ & $\begin{array}{c}0.82 \\
\pm 0.39\end{array}$ & $\begin{array}{c}0.085 \\
\pm 0.021\end{array}$ \\
\hline 2.4 & $\begin{array}{c}5 \\
10 \\
20 \\
30 \\
60 \\
120\end{array}$ & $\begin{array}{c}6.60 \\
12.00 \\
19.65 \\
22.05 \\
25.20 \\
29.70\end{array}$ & $\begin{array}{c}0.91 \\
+0.002\end{array}$ & $\begin{array}{c}0.12 \\
\pm 0.005\end{array}$ & & & & & \\
\hline
\end{tabular}

\section{3. Перспективи використання функціоналізованих S-естерів} тіосульфокислот із 3,4-дизаміщеним бензольним фрагментом

$\mathrm{S}$-естери тіосульфокислот $є$ структурними аналогами естерів тіосульфінових кислот, які проявляють широкий спектр антимікробної дії проти грампозитивних та грамнегативних бактерій та грибів ${ }^{25}$. Слід відзначити, що естери тіосульфінових кислот $є$ менш стабільними порівняно 3 S-естерами тіосульфокислот, які за показниками антимікробної активності не поступаються тіосульфінатам та мають аналогічний механізм антимікробної дії ${ }^{26}$.

\section{Експериментальні дослідження біологічної активності}

Здійснено первинні експериментальні дослідження біологічної активності синтезованих S-естерів тіосульфокислот з 3,4-дизаміщеним бензольним фрагментом методами дифузії та серійних розведень щодо низки тест-мікроорганізмів.

Антимікробна активність S-естерів 2.1-2.3, 4.1-4.3 досліджена поетапно: методом дифузії 3 використанням дисків здійснено попередній відбір препаратів, ефективні концентрації яких у подальшому встановлено методом серійніх розведень ${ }^{27}$.

Фунгібактерицидну активність досліджено методом дифузії 3 використанням дисків (табл. 5). Показано, що всі сполуки, за винятком 9.3, проявляють бактерицидні властивості, максимальні показники яких має метиловий S-естер 3-ацетоксиаміно-4-амінобензолтіосульфокислоти 4.1, а фунгіцидна дія якого є вибірковою щодо досліджених видів грибів ${ }^{28}$.

25 A Comparison of the Antibacterial and Antifungal Activities of Thiosulfnate Analogues of Allicin / R. Leontiev et al. Scientific RePortS. 2018. 8. 1-19. DOI: 10.1038/s41598-018-25154-9

${ }^{26}$ The human allicin-proteome: S-thioallylation of proteins by the garlic defence substance allicin and its biological effects / C.H. Martin et al. Free Radical Biology and Medicine. 2019. 131. 144-153. URL: doi.org/10.1016/j.freeradbiomed.2018.11.022

27 Лабинская А.С. Микробиология с техникой микробиологических исследдований. Москва : Медицина, 1972. 480 с.

${ }^{28}$ Фунгібактерицидна активність деяких тіосульфоестерів / О.3. Комаровська та ін. Вісник НУ «Львівська політехніка». Хімія, технологія речовин та їх застосування. 2001. № 426. С. 137-140. 
Таблиця 5

Результати фунгібактерицидної дії S-естерів тіосульфокислоти

2.1, 2.1, 4.1, 9.3

\begin{tabular}{|c|c|c|c|c|c|c|c|c|c|c|c|c|c|c|}
\hline & \multirow[b]{3}{*}{ 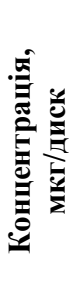 } & \multicolumn{13}{|c|}{ Зона пригнічення росту мікроорганізмів, мм } \\
\hline & & \multicolumn{5}{|c|}{ гриби } & \multicolumn{8}{|c|}{ бактерії } \\
\hline & & 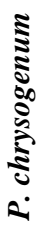 & 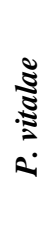 & ه্ষ & 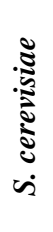 & نّ & 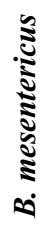 & $\underset{8}{\tilde{8}}$ & 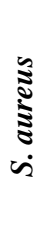 & 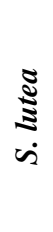 & 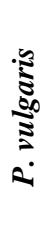 & 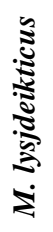 & $\begin{array}{l}\mathbf{\Xi} \\
\mathbf{\Xi} \\
\mathbf{\Xi} \\
\mathbf{z}\end{array}$ & 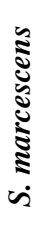 \\
\hline \multirow{3}{*}{2.1} & 100 & 0 & 0 & 0 & 0 & 0 & 15 & 17 & 11 & 25 & 18 & 16 & 28 & 14 \\
\hline & 60 & 0 & 0 & 0 & 0 & 0 & 16 & 15 & 0 & 23 & 19 & 15 & 20 & 15 \\
\hline & 20 & 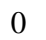 & 0 & 0 & 0 & 0 & 14 & 14 & 0 & 21 & 18 & 12 & 16 & 0 \\
\hline \multirow{3}{*}{2.2} & 100 & 0 & 0 & 0 & 0 & 18 & 12 & 8 & 13 & 13 & 12 & 13 & 26 & 8 \\
\hline & 6 & 0 & 0 & 0 & 0 & 18 & 11 & 7 & 11 & 13 & 11 & 12 & 16 & 7 \\
\hline & 20 & 0 & 0 & 0 & 0 & 17 & 10 & 0 & 10 & 10 & 12 & 13 & 12 & 0 \\
\hline \multirow{3}{*}{4.1} & 100 & 0 & 15 & 0 & 18 & 18 & 17 & 22 & 12 & 17 & 22 & 18 & 18 & 11 \\
\hline & 60 & 0 & 13 & 0 & 16 & 17 & 16 & 18 & 11 & 16 & 22 & 18 & 19 & 12 \\
\hline & 20 & 0 & 0 & 0 & 0 & 11 & 13 & 14 & 0 & 12 & 18 & 15 & 16 & 0 \\
\hline \multirow{3}{*}{9.3} & 100 & 2 & 2 & 6 & 8 & 6 & 0 & S & 0 & 0 & 0 & 0 & 0 & 0 \\
\hline & 60 & 0 & 0 & 2 & 6 & 2 & 0 & 0 & 0 & 0 & 0 & 0 & 0 & 0 \\
\hline & 20 & 0 & 0 & 1 & 2 & 0 & 0 & 0 & 0 & 0 & 0 & 0 & 0 & 0 \\
\hline
\end{tabular}

Вплив сульфонільного або тіольного складників S-естерів 3-ацетиламіно-4-метоксибензолтіосульфокислоти 2.1-2.3 на фунгібактерицидну дію (табл. 6) досліджено порівнянням із дією аналогічних S-естерів 8-хінолінтіосульфокислоти ${ }^{29}$. Встановлено їхню практично однакову бактерицидну активність навіть у мінімальній концентрації 0,1 мг/мл та суттєвий вплив на фунгіцидну дію природи сульфонільного фрагмента. S-Метил(хінолін-8-іл)тіосульфонат повністю пригнічує розвиток Candida albicans в концентрації 1 мг/мл за 48 год, тоді як S-метил-3-ацетиламіно-4-метоксибензолтіосульфонат 2.1 проявляе фунгіцидну дію лише протягом перших 24 год. У концентрації 2 мг/мл і частково затримує розвиток Candida albicans у максимальній досліджуваній концентрації після 48 год. інкубації (табл. 6).

29 Вивчення залежності біологічної активності тіосульфонатів від кислотної і тіольної складової / Д.Б. Баранович та ін. Вісник ДУ «Львівська політехніка». Хімія, технологія речовин та їх застосування. 2000. № 395. С. 96-99. 
Результати фунгібактерицидної дії S-естерів

3-ацетиламіно-4-метоксибензолтіосульфокислоти 2.1-2.3

\begin{tabular}{|c|c|c|c|c|c|c|c|}
\hline & \multirow[b]{2}{*}{$\begin{array}{c}\text { Тест- } \\
\text { препарат }\end{array}$} & \multirow[b]{2}{*}{$\begin{array}{l}\text { Час, } \\
\text { год }\end{array}$} & \multicolumn{5}{|c|}{ Розведення та концентрація препарату } \\
\hline & & & $\begin{array}{c}1: 500 \\
(2 \mathrm{Mг} / \mathbf{M}) \\
\end{array}$ & $\begin{array}{c}1: 1000 \\
(1 м г / м Л) \\
\end{array}$ & $\begin{array}{c}1: 2000 \\
(0.5 \text { мг/мл) } \\
\end{array}$ & $\begin{array}{c}1: 5000 \\
(0.2 \mathrm{Mг} / \text { мл) } \\
\end{array}$ & $\begin{array}{c}1: 10000 \\
(0.1 \text { мг/мл) } \\
\end{array}$ \\
\hline \multirow{2}{*}{2.1} & $\begin{array}{l}\text { Escherihia } \\
\text { coli C- } 600\end{array}$ & $\begin{array}{l}24 \\
48\end{array}$ & $\begin{array}{l}+ \\
+\end{array}$ & $\begin{array}{l}+ \\
+\end{array}$ & $\begin{array}{l}+ \\
+\end{array}$ & $\begin{array}{l}+ \\
+\end{array}$ & $\begin{array}{l}+ \\
\pm\end{array}$ \\
\hline & $\begin{array}{l}\text { Candida } \\
\text { albicans }\end{array}$ & $\begin{array}{l}24 \\
48\end{array}$ & $\begin{array}{l}+ \\
\pm\end{array}$ & $\begin{array}{l} \pm \\
\pm\end{array}$ & \pm & \pm & - \\
\hline \multirow{2}{*}{2.2} & $\begin{array}{l}\text { Escherihia } \\
\text { coli } C-600\end{array}$ & $\begin{array}{l}24 \\
48\end{array}$ & $\begin{array}{l}+ \\
+\end{array}$ & $\begin{array}{l}+ \\
+\end{array}$ & $\begin{array}{l}+ \\
+\end{array}$ & $\begin{array}{l}+ \\
+\end{array}$ & $\begin{array}{l} \pm \\
\pm\end{array}$ \\
\hline & $\begin{array}{l}\text { Candida } \\
\text { albicans }\end{array}$ & $\begin{array}{l}24 \\
48\end{array}$ & $\begin{array}{l}+ \\
+\end{array}$ & $\begin{array}{l}+ \\
+\end{array}$ & $\begin{array}{l}+ \\
+\end{array}$ & $\begin{array}{l}+ \\
+\end{array}$ & $\begin{array}{l}+ \\
\pm\end{array}$ \\
\hline \multirow{2}{*}{2.3} & $\begin{array}{l}\text { Escherihia } \\
\text { coli } C-600\end{array}$ & $\begin{array}{l}24 \\
48\end{array}$ & $\begin{array}{l}+ \\
+\end{array}$ & $\begin{array}{l}+ \\
+\end{array}$ & $\begin{array}{l}+ \\
+\end{array}$ & $\begin{array}{l}+ \\
+\end{array}$ & $\begin{array}{l}+ \\
+\end{array}$ \\
\hline & $\begin{array}{l}\text { Candida } \\
\text { albicans }\end{array}$ & $\begin{array}{l}24 \\
48\end{array}$ & $\begin{array}{l}+ \\
+\end{array}$ & $\begin{array}{l} \pm \\
\pm\end{array}$ & $\begin{array}{l} \pm \\
\pm\end{array}$ & \pm & - \\
\hline
\end{tabular}

\footnotetext{
Примітка: + повна затримка розвитку тест-культур

+ часткова затримка розвитку тест-культур

- відсутність впливу препарату, активний ріст тест-культур
}

Альтернативним шляхом дослідження фунгібактерицидної дії сполук $є$ метод серійних розведень, яким установлено для сполук 2.1-2.3 мінімальні інгібуючі (МІК), мінімальні бактерицидні (МБК) і мінімальні фунгіцидні (МФК) концентрації (табл. 7). Досліджені сполуки є ефективними бактерицидами, а їхня фунгіцидна дія щодо Candida albicans є дещо нижчою.

Таблиця 7

Антимікробна активність S-естерів

3-ацетиламіно-4-метоксибензолтіосульфокислоти 2.1-2.3

\begin{tabular}{|c|c|c|c|c|c|c|}
\hline \multirow{2}{*}{ Естери } & \multicolumn{3}{|c|}{ Мінімальні інгібуючі та біоцидні конентрації, мкг/мЛ } \\
\cline { 2 - 7 } & \multicolumn{2}{|c|}{ S. aureus } & \multicolumn{2}{c|}{ E.coli } & \multicolumn{2}{c|}{ C. albicans } \\
\cline { 2 - 7 } & MIK & MБK & MIK & MБK & MIK & MФK \\
\hline $\mathrm{CH}_{3}-$ & 7,8 & 15,6 & 7,8 & 7,8 & 62,5 & 125 \\
$\mathrm{C}_{2} \mathrm{H}_{5}-$ & 15,6 & 15,6 & 7,8 & 15,6 & 31,2 & 62,5 \\
$\mathrm{CH}_{2}=\mathrm{CH}_{-}-\mathrm{CH}_{2}-$ & 15,6 & 31,2 & 15,6 & 31,2 & 125 & 125 \\
\hline
\end{tabular}

Дослідженням S-естерів 3-аміно-4-метоксибензолтіосульфокислоти 4.1-4.3 на різних штамах бактеріальних тест-культур Arthrobacter, Bacillus, E. coli, Micrococcus, Nocardia, Pseudomonas, Rhodococcus, Staphylococcus встановлено, що у всіх концентраціях ефективними 
бактерицидами є етиловий S-естер 4.2 по відношенню до Rhodococcus rubrum $22 \Gamma$ та Nocardia rubra 15Г, аліловий S-естер 4.3 - до Bacillus $s p$ $5 \mathrm{~d}$, тоді як всі сполуки пригнічують ріст Bacillus sp.9Г у всіх досліджених концентраціях (табл. 8).

Таблиця 8

Результати бактерицидної дії S-естерів 3-аміно-4-метоксибензолтіосульфокислоти 4.1-, 4.3

\begin{tabular}{|c|c|c|c|c|c|c|c|c|c|}
\hline \multirow{3}{*}{$\begin{array}{c}\text { Бактеріальні } \\
\text { тест-культури }\end{array}$} & \multicolumn{9}{|c|}{$\begin{array}{c}\text { S-естери 3-аміно-4-метоксибензолтіосульфокислоти, } \\
\text { концентрація, \% }\end{array}$} \\
\hline & \multicolumn{3}{|c|}{$-\mathrm{CH}_{3}$} & \multicolumn{3}{|c|}{$-\mathrm{C}_{2} \mathrm{H}_{5}$} & \multicolumn{3}{|c|}{$-\mathrm{CH}_{2}=\mathrm{CH}-\mathrm{CH}_{2}$} \\
\hline & 0.1 & 0.01 & 0.001 & 0.1 & 0.01 & 0.001 & 0.1 & 0.01 & 0.001 \\
\hline Arthrobacter $\mathrm{A}_{1} \Gamma$ & + & - & - & + & - & - & + & + & - \\
\hline Arthrobacter $\mathrm{A}_{2} \Gamma$ & + & - & - & + & \pm & - & + & \pm & - \\
\hline Arthrobacter $\mathrm{A}_{3} \Gamma$ & + & - & - & + & \pm & - & + & \pm & - \\
\hline Arthrobacter $\mathrm{A}_{4} \Gamma$ & + & \pm & + & + & \pm & - & + & \pm & - \\
\hline Arthrobacter $\mathrm{A}_{5} \Gamma$ & + & $\bar{t}$ & - & + & \pm & + & + & + & - \\
\hline Bacillus cereus 27A & + & + & - & + & + & + & + & + & - \\
\hline Bacillus larvae $12 \Gamma$ & + & \pm & - & + & \pm & + & + & + & - \\
\hline Bacillus licheniformis $7 \Gamma$ & + & + & - & + & + & + & + & + & - \\
\hline Bacillus mycoides 71d & + & - & - & + & \pm & - & + & \pm & - \\
\hline Bacillus sp 5d & + & + & - & + & \pm & + & + & + & + \\
\hline Bacillus sp $9 \Gamma$ & + & + & + & + & + & + & + & + & + \\
\hline Bacillus subtilis $26 \Gamma$ & + & \pm & - & + & $\underline{ \pm}$ & + & + & $\underline{ \pm}$ & - \\
\hline Escherichia coli 36A & + & - & - & + & $\underline{ \pm}$ & - & + & - & - \\
\hline Escherichia coli 395 & + & + & - & + & + & - & + & - & - \\
\hline Escherichia coli 44D & + & \pm & - & + & + & - & + & - & - \\
\hline Micrococcus $23 \Gamma$ & + & \pm & - & + & \pm & - & + & - & - \\
\hline Micrococcus $25 \Gamma$ & + & - & - & + & \pm & - & + & \pm & - \\
\hline Micrococcus $29 \Gamma$ & + & \pm & - & + & \pm & - & + & \pm & - \\
\hline Micrococcus $31 \Gamma$ & + & + & - & + & + & - & + & + & - \\
\hline Nocardia rubra $15 \Gamma$ & + & + & - & + & + & + & + & + & - \\
\hline Pseudomonas putida 22A & + & + & - & + & \pm & - & + & \pm & - \\
\hline Pseudomonas putida $37 \mathrm{~d}$ & + & \pm & - & + & $\underline{ \pm}$ & - & + & $\underline{ \pm}$ & - \\
\hline Rhodococcus rubrum $22 \Gamma$ & + & + & - & + & + & + & + & + & - \\
\hline $\begin{array}{l}\text { Staphylococcus } \\
\text { epidermidis } 30 \mathrm{~A}\end{array}$ & + & - & - & + & - & - & + & - & - \\
\hline
\end{tabular}

Примітка: + повна затримка розвитку тест-культур

+ часткова затримка розвитку тест-культур

- відсутність впливу препарату, активний ріст тест-культур

Експериментально на тест-об'єктах односім'ядольних (овес) i двосім'ядольних (крес-салат) рослин установлено можливість використання в мізерних концентраціях S-естерів тіосульфокислот 3 3,4-дизаміщеним бензольним фрагментом як інгібіторів або стимуляторів росту рослин залежно від їхньої структури. Ступінь активності та ефективну концентрацію визначає структура субстанції. 


\section{Скринінг прогнозованої активності}

Особливе місце серед важливих характеристик хімічних сполук займає біологічна активність як результат взаємодії хімічної речовини з біологічним об'єктом.

Оскільки будь-яка сполука проявляє декілька видів біологічної активності, оцінку загального біологічного потенціалу речовини для визначення шляхів практичного застосування здійснюють з урахуванням потенційної небезпеки для теплокровних організмів (канцерогенність, мутагенність тощо). У деяких випадках токсичні ефекти використовують для створення нових лікарських засобів, зокрема для онкології.

Сьогодні використовують низку методів хемоінформатики для інтенсифікації експериментальних досліджень, зокрема, застосовують комп'ютерні системи PASS (Prediction of Activity Spectra for Substances) та GUSAR (General Unrestricted Structure-Activity. Relationships), які дозволяють на досинтетичній стадії створення потенційних субстанцій кількісно оцінити їхню біологічну активність і токсичність.

Раціональним шляхом доекспериментальних досліджень визначення фізіологічної дії новосинтезованих сполук $\epsilon$ використання комп’ютерної системи GUSAR ${ }^{30}$, на основі результатів вибірки якої можна зменшити затрати на синтетичний блок створення нових біологічно активних об'єктів.

Навчальні набори програми GUSAR створено на основі даних бази даних токсичності MDL SYMYX, вони включають інформацію щодо 10000 хімічних структур із даними про гостру токсичність щурів, представленими як значення $\mathrm{LD}_{50}(\log 10, \text { ммоль/кг })^{31}$. Решта прогностичних параметрів здатності програми GUSAR використані за замовчуванням. Як внутрішню валідацію використано змінний контроль із двадцятикратним виключенням 20\% навчальної вибірки.

Застосуванням консенсусного підходу, який реалізовано в програмі GUSAR, здійснено з використанням фармакокінетичної моделі оцінку гострої токсичності щодо щурів на основі внутрішнього або інгаляційного способу введення (табл. 9). Класифікацію речовин за ступенем токсичності оцінено відповідно до СОУ 85.2-37-736:2011.

Перелік протестованих синтезованих сполук розширений речовинами, порівняння 3 якими може дати додаткову інформацію щодо кореляції взаємозв'язку особливостей будови 3 біологічною активністю: алкіловим S-естером 3-аміно-4-метоксибензентіосульфокислоти 4.4, S-аліл-3-метил-4-етиламінобензентіосульфонатом 5.2,

${ }^{30}$ QNA-based 'Star Track' QSAR approach / D.A. Filimonov et al. Journal SAR and QSAR in Environmental Research. 2009. 20. 679-709. URL: https://doi.org/ 10.1080/10629360903438370

GUSAR software online. URL: http://www.pharmaexpert.ru/GUSAR/ AcuToxPredict/ (дата звернення: 04.03.2020). 
S-(3-хлоро-2-гідроксипропіл)-3-метокси-4-амінобензентіосульфонатом 7.2, а також монозаміщеними S-метил- 10.1 і $\mathrm{S}$-етил-4(N-етил$\mathrm{N}$-ацетиламіно)бензентіосульфонатами 10.2.

Встановлено, що введення 3,4-дизаміщеної бензольної складової у тіольний фрагмент дає естери $(9.1,9.3,9.5,9.8) 5$-го класу токсичності незалежно від способу внутрішнього введення (IP, IV, SC), інші протестовані S-естери тіосульфокислот із 3,4-дизаміщеним бензольним складником у сульфонільному фрагменті відносяться до 4-го класу токсичності, тоді як за інгаляційного введення ці сполуки $\epsilon$ малотоксичними (5-й клас) (табл. 9). Виділено сполуки-лідери S-[2-(3аміно-4-метоксибензенсульфоніл)етил]-4-амінобензентіосульфонат 9.1 i S-[2-(3-аміно-4-метоксибензен-сульфоніл)етил]бензентіосульфонат 9.5, що дозволяє їх розглядати як потенційні малотоксичні потенційні субстанції, на основі яких можуть бути створені нові лікарські засоби.

Таблиця 9

Результати прогнозування гострої токсичності щодо гризунів на основі вибірки програми GUSAR сполук-лідерів

\begin{tabular}{|c|c|c|c|c|c|}
\hline \multirow{2}{*}{ № } & \multicolumn{5}{|c|}{ Гостра токсичність щодо щурів за проектом OECD } \\
\hline & & $I P L D_{50}$ & $I V L D_{50}$ & Oral $L D_{50}$ & $S C L D_{50}$ \\
\hline \multirow{3}{*}{2.1} & $\mathrm{mmol} / \mathrm{kg}$ & 0,266 in $\mathrm{AD}$ & 0,062 in $\mathrm{AD}$ & 0,523 in $\mathrm{AD}$ & 0,244 out of $\mathrm{AD}$ \\
\hline & $m g / k g$ & 508,600 in $\mathrm{AD}$ & $\begin{array}{c}317,700 \text { in } \\
\text { AD }\end{array}$ & 917,900 in $\mathrm{AD}$ & 483,000 out of $\mathrm{AD}$ \\
\hline & Class & 5 in $\mathrm{AD}$ & 5 in $\mathrm{AD}$ & 4 in $\mathrm{AD}$ & 4 out of $\mathrm{AD}$ \\
\hline \multirow{3}{*}{4.1} & $\mathrm{mmol} / \mathrm{kg}$ & 0,191 in $\mathrm{AD}$ & 0,132 in $\mathrm{AD}$ & 0,434 in $\mathrm{AD}$ & 0,240 in $\mathrm{AD}$ \\
\hline & $m g / k g$ & 362,500 in $\mathrm{AD}$ & $\begin{array}{c}315,900 \text { in } \\
\text { AD }\end{array}$ & 633,100 in $\mathrm{AD}$ & 405,700 in $\mathrm{AD}$ \\
\hline & Class & 4 in $\mathrm{AD}$ & 5 in $\mathrm{AD}$ & 4 in $\mathrm{AD}$ & 4 in $\mathrm{AD}$ \\
\hline \multirow{3}{*}{9.1} & $\mathrm{mmol} / \mathrm{kg}$ & 0,266 in $\mathrm{AD}$ & 0,094 in $\mathrm{AD}$ & 0,628 in $\mathrm{AD}$ & 0,694 in $\mathrm{AD}$ \\
\hline & $\mathrm{mg} / \mathrm{kg}$ & 742,200 in $\mathrm{AD}$ & $\begin{array}{c}500,100 \text { in } \\
\text { AD }\end{array}$ & $\begin{array}{c}1711,000 \text { in } \\
\text { AD }\end{array}$ & 1991,000 in $\mathrm{AD}$ \\
\hline & Class & 5 in $A D$ & 5 in $A D$ & 4 in $A D$ & 5 in $\mathrm{AD}$ \\
\hline \multirow{3}{*}{9.3} & $\mathrm{mmol} / \mathrm{kg}$ & 0,367 in $\mathrm{AD}$ & $-0,137$ in $\mathrm{AD}$ & 0,213 in $\mathrm{AD}$ & 0,577 out of $\mathrm{AD}$ \\
\hline & $\mathrm{mg} / \mathrm{kg}$ & 934,900 in $\mathrm{AD}$ & $\begin{array}{c}292,900 \text { in } \\
\text { AD }\end{array}$ & 656,500 in $\mathrm{AD}$ & $\begin{array}{c}1514,000 \text { out of } \\
\mathrm{AD}\end{array}$ \\
\hline & Class & 5 in $A D$ & 4 in $A D$ & 4 in $A D$ & 5 out of $\mathrm{AD}$ \\
\hline \multirow{3}{*}{9.5} & $\mathrm{mmol} / \mathrm{kg}$ & 0,326 in $\mathrm{AD}$ & 0,036 in $\mathrm{AD}$ & 0,389 in $\mathrm{AD}$ & 0,705 in $\mathrm{AD}$ \\
\hline & $m g / k g$ & 820,200 in $\mathrm{AD}$ & $\begin{array}{c}420,700 \text { in } \\
\text { AD }\end{array}$ & 948,600 in $\mathrm{AD}$ & 1964,000 in $\mathrm{AD}$ \\
\hline & Class & 5 in $A D$ & 5 in $A D$ & 4 in $A D$ & 5 in $A D$ \\
\hline \multirow{3}{*}{9.8} & $\mathrm{mmol} / \mathrm{kg}$ & 0,235 out of $\mathrm{AD}$ & 0,083 in $\mathrm{AD}$ & 0,541 in $\mathrm{AD}$ & 0,396 in $\mathrm{AD}$ \\
\hline & $\mathrm{mg} / \mathrm{kg}$ & $\begin{array}{c}583,600 \text { out of } \\
\text { AD }\end{array}$ & $\begin{array}{c}411,100 \text { in } \\
\text { AD }\end{array}$ & $\begin{array}{c}1181,000 \text { in } \\
\text { AD }\end{array}$ & 844,800 in $\mathrm{AD}$ \\
\hline & Class & 5 out of $\mathrm{AD}$ & 5 in $\mathrm{AD}$ & 4 in $A D$ & 4 in $A D$ \\
\hline
\end{tabular}

Примітка: IP-внутрішньочеревне введення

IV - внутрішньовенне введення $S C$ - підикірне введення in $A D$ - внутрішнє введення Oral-nероральне введення out of $A D$ - інгаляційний спосіб 
На основі результатів скринінгу із застосуванням програми GUSAR проаналізовано потенційну можливість використання досліджуваних сполук як синтетичних субстанцій для комбінованої хіміотерапії або хіміотерапії першої лінії.

Цитотоксичну активність $\mathrm{S}$-естерів тіосульфокислот iз 3,4-дизаміщеним бензольним фрагментом спрогнозовано для ліній клітин раку з урахуванням органу ураження (гемопоетична і лімфоїдна тканини, легені, шкіра, кров, яєчник, товста кишка, нирки, молочна залоза) та типу злоякісного новоутворення (лімфома, карцинома, меланома, лейкемія, аденокарцинома) (табл. 10).

Таблиця 10

Результати прогнозування цитотоксичності S-естерів тіосульфокислот на основі вибірки програми GUSAR

\begin{tabular}{|c|c|c|c|c|c|c|c|c|c|c|}
\hline $\begin{array}{c}\text { Лінія клітин } \\
\text { раку / шифр }\end{array}$ & $\mathbf{2 . 1}$ & $\mathbf{2 . 2}$ & $\mathbf{2 . 3}$ & $\mathbf{2 . 4}$ & $\mathbf{4 . 1}$ & $\mathbf{4 . 2}$ & $\mathbf{4 . 3}$ & $\mathbf{4 . 4}$ & 7.1 & 7.2 \\
\hline $\begin{array}{c}\text { Acute T- } \\
\text { lymphoblastic } \\
\text { leukemia / } \\
\text { MOLT-4 }\end{array}$ & 0.894 & 0.832 & 0.858 & 0.735 & 0.891 & 0.894 & 0.930 & 0.844 & 0.724 & 0.842 \\
\hline $\begin{array}{c}\text { Adult } \\
\text { immunoblastic } \\
\text { lymphoma / SR }\end{array}$ & 0.991 & 0.987 & 0.978 & 0.981 & 0.992 & 0.991 & 0.987 & 0.987 & 0.970 & 0.983 \\
\hline $\begin{array}{c}\text { Breast } \\
\text { carcinoma / } \\
\text { MCF7 }\end{array}$ & 0.750 & 0.661 & 0.513 & 0.657 & 0.802 & 0.750 & 0.633 & 0.737 & 0.680 & 0.769 \\
\hline $\begin{array}{c}\text { Colon } \\
\text { adenocarcinoma } \\
\text { / HCC 2998 }\end{array}$ & 0.898 & 0.868 & 0.726 & 0.779 & 0.889 & 0.898 & 0.801 & 0.820 & 0.755 & 0.815 \\
\hline $\begin{array}{c}\text { Lung carcinoma } \\
\text { / A549 }\end{array}$ & 0.982 & 0.945 & 0.853 & 0.924 & 0.995 & 0.982 & 0.955 & 0.972 & 0.825 & 0.932 \\
\hline $\begin{array}{c}\text { Melanoma / SK- } \\
\text { MEL-5 }\end{array}$ & 0.943 & 0.921 & 0.886 & 0.891 & 0.947 & 0.943 & 0.910 & 0.906 & 0.873 & 0.897 \\
\hline $\begin{array}{c}\text { Melanoma / } \\
\text { UACC-257 }\end{array}$ & 0.842 & 0.827 & 0.709 & 0.748 & 0.835 & 0.842 & 0.785 & 0.794 & 0.699 & 0.765 \\
\hline $\begin{array}{c}\text { Melanoma / } \\
\text { Malme-3M }\end{array}$ & 0.678 & 0.674 & 0.608 & 0.658 & 0.647 & 0.678 & 0.617 & 0.659 & 0.528 & 0.523 \\
\hline $\begin{array}{c}\text { Non-small c ell } \\
\text { lung carcinoma } \\
\text { / NCI-H522 }\end{array}$ & 0.958 & 0.947 & 0.906 & 0.912 & 0.960 & 0.958 & 0.944 & 0.940 & 0.894 & 0.931 \\
\hline $\begin{array}{c}\text { Non-small cell } \\
\text { lung carcinoma } \\
\text { / HOP-92 }\end{array}$ & 0.958 & 0.942 & 0.903 & 0.914 & 0.960 & 0.958 & 0.938 & 0.939 & 0.889 & 0.926 \\
\hline $\begin{array}{c}\text { Ovarian } \\
\text { adenocarcinoma } \\
\text { / IGROV-1 }\end{array}$ & 0.879 & 0.823 & 0.716 & 0.778 & 0.879 & 0.879 & 0.788 & 0.839 & 0.706 & 0.766 \\
\hline $\begin{array}{c}\text { Promyeloblast } \\
\text { leukemia / HL- } \\
\text { 60 }\end{array}$ & - & - & - & - & 0.515 & - & 0.622 & - & - & - \\
\hline $\begin{array}{c}\text { Renal } \\
\text { carcinoma / } \\
786-0\end{array}$ & 0.812 & 0.767 & 0.674 & 0.734 & 0.792 & 0.812 & 0.739 & 0.773 & 0.687 & 0.743 \\
\hline
\end{tabular}


Продовження таблиці 10

\begin{tabular}{|c|c|c|c|c|c|c|c|c|c|c|}
\hline \multirow{2}{*}{$\begin{array}{l}\text { Лінія клітин } \\
\text { раку / шифр }\end{array}$} & \multicolumn{10}{|c|}{ Сполуки-кандидати } \\
\hline & 5.1 & 5.2 & 6.1 & 6.2 & 9.1 & 9.3 & 9.5 & 9.8 & 10.1 & 10.2 \\
\hline $\begin{array}{c}\text { Acute T- } \\
\text { lymphoblastic } \\
\text { leukemia / } \\
M O L T-4\end{array}$ & 0.862 & 0.895 & 0.731 & 0.834 & 0.895 & 0.862 & 0.889 & 0.611 & 0.833 & 0.861 \\
\hline $\begin{array}{c}\text { Adult } \\
\text { immunoblastic } \\
\text { lymphoma / SR }\end{array}$ & 0.989 & 0.984 & 0.984 & 0.977 & 0.988 & 0.983 & 0.989 & 0.782 & 0.991 & 0.991 \\
\hline $\begin{array}{c}\text { Breast } \\
\text { carcinoma / } \\
M C F 7\end{array}$ & 0.697 & 0.502 & - & - & 0.595 & 0.553 & 0.614 & - & 0.616 & 0.573 \\
\hline $\begin{array}{c}\text { Colon } \\
\text { adenocarcinoma } \\
\text { / HCC } 2998\end{array}$ & 0.866 & 0.777 & 0.750 & 0.652 & 0.789 & 0.723 & 0.798 & - & 0.877 & 0.900 \\
\hline $\begin{array}{c}\text { Lung carcinoma } \\
\text { / } A 549\end{array}$ & 0.983 & 0.903 & 0.967 & 0.845 & 0.940 & 0.910 & 0.956 & - & 0.986 & 0.973 \\
\hline $\begin{array}{c}\text { Melanoma / SK- } \\
M E L-5\end{array}$ & 0.925 & 0.894 & 0.894 & 0.864 & 0.936 & 0.917 & 0.941 & 0.525 & 0.942 & 0.949 \\
\hline $\begin{array}{c}\text { Melanoma / } \\
U A C C-257\end{array}$ & 0.803 & 0.706 & 0.719 & 0.670 & 0.818 & 0.775 & 0.822 & - & 0.835 & 0.849 \\
\hline $\begin{array}{l}\text { Melanoma / } \\
\text { Malme-3M }\end{array}$ & 0.642 & 0.612 & 0.531 & - & 0.635 & 0.601 & 0.642 & - & 0.663 & 0.700 \\
\hline $\begin{array}{l}\text { Non-small c ell } \\
\text { lung carcinoma } \\
\text { / NCI-H522 }\end{array}$ & 0.952 & 0.924 & 0.933 & 0.892 & 0.952 & 0.937 & 0.954 & 0.658 & 0.959 & 0.961 \\
\hline $\begin{array}{c}\text { Non-small cell } \\
\text { lung carcinoma } \\
\text { / HOP-92 }\end{array}$ & 0.951 & 0.925 & 0.925 & 0.903 & 0.948 & 0.934 & 0.950 & - & 0.956 & 0.960 \\
\hline $\begin{array}{c}\text { Ovarian } \\
\text { adenocarcinoma } \\
\text { / IGROV-1 }\end{array}$ & 0.831 & 0.742 & 0.778 & 0.713 & 0.821 & 0.763 & 0.831 & - & 0.866 & 0.886 \\
\hline $\begin{array}{c}\text { Promyeloblast } \\
\text { leukemia / } H L \text { - } \\
60\end{array}$ & - & 0.501 & - & - & - & - & - & - & - & - \\
\hline $\begin{array}{c}\text { Renal } \\
\text { carcinoma / } \\
786-0\end{array}$ & 0.752 & 0.694 & 0.679 & 0.623 & 0.733 & 0.705 & 0.752 & - & 0.781 & 0.822 \\
\hline
\end{tabular}

Основним принципом вибору препаратів для медикаментозного лікування в онкології $є$ максимальна ефективність щодо певного типу пухлини на фоні найменшої токсичності, що мінімізує ризики для пацієнта, оскільки зниження функцій органів і систем до III-IV ступеня за класифікацією ВОO3 та Міжнародного протиракового союзу $\epsilon$ протипоказанням до застосування протипухлинних препаратів ${ }^{32}$.

Потенційними перспективними субстанціями 3 прогнозованою протипухлинною дією (програма GUSAR) можна рекомендувати для подальших експериментальних досліджень S-естери тіосульфокислот 3 3,4-дизаміщеним бензольним фрагментом, що відносяться до 5-го класу токсичності, прогнозована протипухлинна дія яких за внутрішньовенного введення відносно окремих ліній клітин раку становить 99\%.

32 Онкологія / за ред. Б.Т. Білинського, Ю.М. Стернюка, Я.В. Шпарика. Львів : Медицина світу, 1998. 272 с. 
Комп'ютерна програма PASS здійснює фармакологічний скринінг на основі аналізу взаємозв'язків «структура-активність» бібліотеки навчальної вибірки сполук 3 експериментально встановленою біологічною дією (понад 250407 біологічно активних потенційних i відомих субстанцій), що дозволяє за структурною формулою спрогнозувати із середньою точністю до $85 \%$ у разі змінного контролю з виключенням по одному понад 8000 видів біологічної активності, які включають основні та побічні фармакологічні ефекти, механізми дії, канцерогенність, ембріотоксичність, мутагенність, тератогенність тощо ${ }^{33}$.

Використанням програми PASS проведено прогнозування спектру біологічної активності синтезованих функціоналізованих S-естерів тіосульфокислот із 3,4-дизаміщеним бензольним фрагментом (загальна кількість протестованих сполук - 20, загальна кількість видів активності, щодо яких отримано результат, - понад 200) (табл. 11). Результати прогнозування різних видів активності S-естерів тіосульфокислот знаходяться в межах $0,5<\mathrm{P}_{\mathrm{a}}<0,9$, що в окремих випадках практично підтверджено результатами експериментальних досліджень.

\section{Таблиця 11}

Загальні результати прогнозованого фармакологічного скринінгу S-естерів тіосульфокислот (програма PASS)

\begin{tabular}{|c|c|c|c|c|c|c|}
\hline \multirow{2}{*}{$\begin{array}{c}\text { Загальна } \\
\text { кількість } \\
\text { протестованих } \\
\text { сполук } \\
\end{array}$} & \multirow{2}{*}{$\begin{array}{c}\text { Загальна } \\
\text { кількість } \\
\text { протестованих } \\
\text { видів активності }\end{array}$} & \multicolumn{4}{|c|}{ Сполуки-кандидати } & \multirow[b]{2}{*}{$\begin{array}{c}\text { Сполуки- } \\
\text { лідери } \\
\mathrm{p}_{\mathrm{a}}>90 \%\end{array}$} \\
\hline & & $\begin{array}{l}\mathrm{p}_{\mathrm{a}}> \\
50 \%\end{array}$ & $\begin{array}{l}\mathrm{p}_{\mathrm{a}}> \\
60 \%\end{array}$ & $\begin{array}{l}\mathrm{p}_{\mathrm{a}}> \\
70 \%\end{array}$ & $\begin{array}{l}\mathrm{p}_{\mathrm{a}}> \\
80 \%\end{array}$ & \\
\hline 20 & $>200$ & 61 & 23 & 5 & 2 & 0 \\
\hline
\end{tabular}

Результати фармакологічного скринінгу з використанням програми PASS ілюструють, що протестовані S-естери тіосульфокислот 3 3,4дизаміщеним бензольним фрагментом мають вибіркову фізіологічну активність і $\epsilon$ інгібіторами низки ферментів. Для більшості досліджених $\mathrm{S}$-естерів тіосульфокислот, а саме сполук 2.1, 2.3, 4.1, 4.3, $5.1,5.2,6.2,9.1,9.3,9.5$ і 9.8, характерна хемопротекторна дія, тоді як для деяких речовин $(2.3,4.2,4.3,6.2)$ слід відмітити їхню прогнозовану протигрибкову активність, для сполуки 6.2 - антигельмінтну, для сполуки 9.8 - протизапальну дії. S-естери 4.1-4.4 є інгібіторами тіолоксидази (thiol oxidase inhibitor).

33 geneXplain platform. URL: http:/genexplain.com/pass/ (дата звернення: 04.03.2020). 
Таблиця 12

Результати прогнозованого фармакологічного скринінгу

S-естерів тіосульфокислот (програма PASS)

\begin{tabular}{|c|c|c|c|c|c|c|c|c|c|c|}
\hline \multirow{2}{*}{ Види активності } & \multicolumn{10}{|c|}{ Сполуки-кандидати } \\
\hline & 2.1 & 2.2 & 2.3 & 2.4 & 4.1 & 4.2 & 4.3 & 4.4 & 7.1 & 7.2 \\
\hline $\begin{array}{l}\text { Aldehyde oxidase } \\
\text { inhibitor }\end{array}$ & - & - & - & - & 0,573 & 0,532 & - & 0,553 & - & - \\
\hline Antifungal & - & 0,422 & 0,549 & - & 0,395 & 0,533 & 0,626 & 0,414 & 0,336 & 0,415 \\
\hline Apoptosis agonist & - & - & 0,718 & - & - & - & 0,851 & - & - & 0,455 \\
\hline $\begin{array}{c}\text { Aspulvinone } \\
\text { dimethylallyltransferase } \\
\text { inhibitor }\end{array}$ & 0,544 & 0,500 & 0,494 & 0,467 & 0,706 & 0,676 & 0,664 & 0,647 & - & - \\
\hline Chemoprotective & 0,509 & & 0,747 & & 0,562 & 0,327 & 0,776 & - & - & 0,342 \\
\hline $\begin{array}{c}\text { Gluconate 2- } \\
\text { dehydrogenase } \\
\text { (acceptor) inhibitor }\end{array}$ & 0,493 & 0,464 & 0,617 & 0,454 & 0,388 & 0,451 & 0,574 & - & 0,480 & - \\
\hline Peroxidase inhibitor & $\begin{array}{c}- \\
\end{array}$ & - & $\begin{array}{c}- \\
\end{array}$ & - & 0,440 & 0,610 & 0,311 & 0,588 & & \\
\hline $\begin{array}{c}\text { Polyporopepsin } \\
\text { inhibitor }\end{array}$ & 0,419 & 0,383 & - & 0,435 & 0,406 & 0,397 & & 0,449 & 0,526 & 0,493 \\
\hline $\begin{array}{l}\text { Sulfur reductase } \\
\text { inhibitor }\end{array}$ & 0,357 & 0,434 & 0,324 & 0,444 & 0,406 & 0,496 & 0,373 & 0,506 & - & 0,514 \\
\hline Thiol oxidase inhibitor & - & - & - & - & 0,592 & 0,695 & 0,529 & 0,622 & - & 0,312 \\
\hline Thioredoxin inhibitor & 0,352 & 0,377 & & 0,423 & 0,433 & 0,471 & 0,322 & 0,519 & - & 0,672 \\
\hline $\begin{array}{c}\text { TP53 expression } \\
\text { enhancer }\end{array}$ & - & 0,408 & 0,590 & - & 0,353 & 0,480 & 0,638 & - & 0,515 & - \\
\hline TRPA1 agonist & - & $\begin{array}{l}- \\
\end{array}$ & 0,371 & - & $\begin{array}{c}- \\
\end{array}$ & - & 0,500 & - & $\begin{array}{c}- \\
\end{array}$ & 0,561 \\
\hline Acaricide & - & - & 0,667 & 0,431 & - & - & - & - & - & - \\
\hline $\begin{array}{c}\text { Alanine-tRNA ligase } \\
\text { inhibitor }\end{array}$ & 0,462 & 0,304 & 0,353 & 0,338 & - & - & - & - & 0,462 & 0,562 \\
\hline $\begin{array}{l}\text { Aldehyde oxidase } \\
\text { inhibitor }\end{array}$ & - & 0,651 & - & - & - & - & - & - & - & - \\
\hline Antifungal & - & 0,433 & - & 0,511 & - & - & - & - & - & 0,328 \\
\hline Antiinflammatory & - & - & 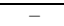 & 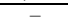 & 0,688 & - & 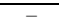 & 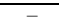 & 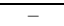 & - \\
\hline Apoptosis agonist & - & & & 0,582 & & & & & & \\
\hline $\begin{array}{l}\text { Arylsulfate } \\
\text { sulfotransferase } \\
\text { inhibitor }\end{array}$ & 0,354 & 0,620 & - & - & - & - & - & - & - & - \\
\hline $\begin{array}{c}\text { Aspulvinone } \\
\text { dimethylallyltransferase } \\
\text { inhibitor }\end{array}$ & - & 0,681 & - & - & 0,552 & 0,387 & 0,414 & 0,496 & - & - \\
\hline $\begin{array}{c}\text { Benzoate-CoA ligase } \\
\text { inhibitor }\end{array}$ & 0,582 & 0,609 & 0,494 & 0,473 & - & - & - & - & 0,473 & 0,543 \\
\hline Chemoprotective & 0,519 & 0,594 & 0,435 & 0,725 & 0,599 & 0,665 & 0,680 & 0,695 & 0,555 & 0,328 \\
\hline CYP2C12 substrate & $\begin{array}{llll}- & & & \\
-\end{array}$ & 0,624 & $\begin{array}{llll}- & & & \\
\end{array}$ & $\begin{array}{llllllllll}- & & & & & & \end{array}$ & $\begin{array}{llll}- & & & \\
\end{array}$ & $\begin{array}{llllllllll}- & & & & & & \end{array}$ & $\begin{array}{lllll}- & & & & \\
\end{array}$ & $\begin{array}{llllllllll}- & & & & & & \end{array}$ & $\begin{array}{llll}- & & & \\
\end{array}$ & $\begin{array}{llll}- & & & \\
\end{array}$ \\
\hline $\begin{array}{c}\text { Phospholipid- } \\
\text { translocating ATPase } \\
\text { inhibitor }\end{array}$ & 0,554 & 0,479 & 0,474 & - & - & - & - & - & 0,649 & 0,617 \\
\hline
\end{tabular}

\section{ВИСНОВКИ}

З огляду на представлені в даній роботі результати досліджень щодо синтезу, хімічних властивостей, експериментальних і прогнозованих біологічних властивостей $\mathrm{S}$-естерів тіосульфокислот із 3,4дизаміщеним бензольним фрагментом проілюстровано, що ці сполуки $€$ перспективними, практично цінними речовинами.

Показано існування кореляції між структурою S-естерів тіосульфокислот, їхньою реакційною здатністю в хімічних i біохімічних реакціях та біологічною активністю, яка базується на специфіці впливу сульфонільної та тіольної компоненти досліджених сполук на їхні інгібуючу та цидну дії проти грампозитивних і грамнегативних бактерій та проти різних видів грибів, що підтверджено експериментальними дослідженнями. 
$\mathrm{S}$-естери тіосульфокислот із 3,4-дизаміщеним бензольним фрагментом $є$ інгібіторами активності ряду ферментів, що встановлено даними прогнозованого скринінгу механізму їхньої дії за програмою PASS.

Результати прогнозування різних видів активності S-естерів тіосульфокислот з використанням програми PASS знаходяться в межах $0,5<\mathrm{P}_{\mathrm{a}}<0,9$, що в окремих випадках практично підтверджено результатами первинних експериментальних досліджень.

Емпіричні дослідження гострої токсичності 3 використанням програми GUSAR відносять досліджені сполуки до 4-5 класу токсичності за міжнародною класифікацією, що відкриває перспективні напрями пошуку нових практично цінних субстанцій, зокрема нових сполук із цитотоксичною дією.

Визначено шляхи практичного застосування S-естерів тіосульфокислот із 3,4-дизаміщеним бензольним фрагментом як рістрегуляторів (рістстимулятрів, рістінгібіторів) односім'ядольних (овес) i двосім'ядольних (крес-салат) рослин та ефективних протигрибкових субстанцій для захисту рослин.

\section{АНОТАЦІЯ}

За останні роки значно зросла увага науковців до дисульфуровмісних сполук, а саме до S-естерів тіосульфокислот 3 функціональними фрагментами зі сторони сульфонільного та тіольного сульфуру, оскільки сферу досліджень цього класу сполук розширили хімічна, фармацевтична, агрохімічна та полімерна галузі. Крім того, $\mathrm{S}$-естери тіосульфокислот $\epsilon$ малотоксичними та входять до складу компонентів, виділених із природної сировини - рослин роду Allium (ріпчата цибуля Allium cepa L., часник Allium sativum L.), цвітна капуста Brassicaoleracea L. var. botrytis та деяких морських водоростей.

Сьогодні дані сполуки все більше значення знаходять у сучасній синтетичній хімії як сульфеніліюючі та сульфонілюючі реагенти.

Запропоновано синтетичні шляхи та умови отримання S-естерів тіосульфокислот із 3,4-дизаміщеним бензольним фрагментом різними шляхами: класичною схемою синтезу взаємодією солей лужних металів тіосульфокислот 3 відповідними алкілюючими реагентами (алклгалогенідами, диметилсульфатом), конденсацією солей тіосульфокислот із натрієвою сіллю 3-аміно-4-метоксибензенсульфонілетилсульфокислоти, взаємодією з оксиранами. Проілюстровано в окремих випадках можливість використання альтернативних шляхів синтезу S-естерів 3-аміно-4-метоксибензентіосульфокислоти.

Оцінено реакційну здатність синтезованих S-естерів тіосульфокислот із 3,4-дизаміщеним бензольним фрагментом в умовах лужного гідролізу та вплив природи сульфонільного та тіольного 
фрагментів на ступінь конверсії для встановлення стабільності сполук залежно від $\mathrm{pH}$ середовища.

Визначено закономірності біологічної активності (гострої токсичності, цитотоксичночті, антимікробної, рістрегулюючої тощо) від будови досліджуваних сполук на основі експериментального i комп’ютерного скринінгу (програми GUSAR та PASS). Визначено напрями подальших експериментальних досліджень 3 метою встановлення практично цінних властивостей синтезованих нових біологічно активних сполук тіосульфонатної структури.

\section{ЛITEPATУРA}

1. Thiosulfonates as Emerging Reactants: Synthesis and Applications Adv. Synth. Catal / P. Mampuys et al. 2020. 362. 3-64. DOI: 10.1002/adsc. 201900864

2. Оае С. Химия органических соединений серы : пер. с япон. ; под ред. Е.Н. Прилежаевой. Москва : Химия, 1975. 512 с.

3. Бартон Д., Оллис У.Д. Общая органическая химия ; ред. Н.К. Кочетков. Москва : Химия, 1983. Том 5: Соединения фосфора и серы. 720 с.

4. Лубенець В.І. Тіосульфонати: синтез і властивості. Укр. хім. ж. 2003. T. 69 (8). C. 114-122.

5. Естери тіосульфокислот: одержання, властивості та перспективи застосування / Н.Я. Монька та ін. Укр. хім. ж. 2018. Т. 84. № (9/10). C. 65-97. URL: https://ucj.org.ua/index.php/journal/issue/ view/9/10-2018 (дата звернення: 02.03.2020).

6. Synthesis and study of pesticidal activity of some N-arylthio-1,4benzoquinone imines / L. Kuzmenko et al. Biointerface Research in Applied Chemistry. 2019. Vol. 9. Iss. 5. 4232-4238.

7. (March 15th 2019). Thiosulfonates: The Prospective Substances against Fungal Infections. In: Fungal Infection / V. Lubenets et al. ; Eds. Érico Silva de Loreto and Juliana Simoni Moraes Tondolo, IntechOpen, London. DOI: 10.5772/intechopen.84436

8. Synthesis and antimicrobial properties of 4-acylaminobenzenethiosulfoacid S-esters / V. Lubenets et al. Saudi Pharmaceutical Journal. 2017. Vol. 25 (2). 266-274. DOI: http://dx.doi.org/10.1016/j.jsps.2016.06.007

9. Synthesis and anti-platelet activity of thiosulfonate derivatives containing a quinone moiety / Kh. Bolibrukh et al. Scientia Pharmaceutica. 2015. Vol. 83. 221-231. URL: https://www.researchgate.net/publication/ 281438155

10. Aktywnosc przeciwgrzybicza syntetycznych pochodnych allicyny kontynuacja badan / Urzula Nawrot et al. Mikologia Lekarska. 2012. Vol. 4. № 19. 143-146. URL: http://cornetis.pl/artykul/5853.html 
11. The search of compounds with antiaggregation activity among S-esters of thiosulfonic acids. / T.I. Halenova et al. Ukr. Biochem. J. 2015. 87 (5). 83-92. DOI: https://doi.org/10.15407/ubj87.05.083

12. Synthesis of new thiosulfonate derivatives with quinone and quinoxaline fragments/ Kh. Bolibrukh et al. Chemical Technology. 2013. Vol. 63. 14-20.

13. The importance of rhamnolipid- biosurfactant induced changes in bacterial membrane lipids of Bacillus subtilis for the antimicrobial activity of thiosulfonates / Anna Sotirova et al. Curr. Microbiol. 2012. Vol. 65 (5). 534-541. URL: http://link.springer.com/article/10.1007/s00284-012-0191-7

14. Synthesis Method for Thiosulfonate and Report of Its Insecticidal Activity in Anagasta kuehniella (Lepidoptera Pyralidae) / E. Santos et al. Int. J. Mol. Sci. 2012. Vol. 13. 15241-15251. DOI: 10.3390/ijms131115241

15. Modification of Alkyl Esters of 4-Aminobenzenethiosulfonic Acid by s-Triazine Fragment and Investigation of their Growth-Regulative Activity / S. Vasylyuk et al. Chem. \& Chem. Technol. 2018. Vol. 12. № 1. 24-28. URL: https://doi.org/10.23939/chcht12.01.024

16. Influence of surfaceactive rhamnolipid biocomplex and ethylthiosulfanilate on growth and biochemical parameters of plants in oil contaminated soil / A.R. Banya et al. Biotechnologia Acta. 2015.8 (5). 7177. DOI: $10.15407 /$ biotech8.05.071

17. Нові технології ефективного захисту текстилю від мікробіологічних пошкоджень / I.А. Мартиросян та ін. Наносистеми, наноматеріали, нанотехнології. Щоквартальний збірник наукових праць. Київ : РВВ ІМФ, 2019. Т. 17. № (4). С. 621-636. PACS numbers: 81.05.Lg, 81.16.Fg, 83.80.Mc, 87.85.jf, 87.85.Rs, 87.85.M

18. Патент 2573077 Франція : МКИ С 07 D 235/28, А 61 К 31/47. Nouveaux derives thiosulfonates, leur procede de preparation ainsi que les compositions pharmaceutiques les contenant / Sebille Bernard, Beuzard Yves, Demarne Henri (Франція). № 8417286 ; заявлен. 13.11 .84 ; опубл. 16.05.86, РЖХ. 9О138П.

19. The S-methyl-(2-methoxycarbonylaminobenzoimidasole-5) thiosulfonate as potential antiparasitic agent - action on development of Ascaris suum eggs in vitro / M. Dmitryjuk et al. Annals of Parasitology. 2019. Vol. 65. supplement 1: Abstracts of the XXV Congress of the Polish Parasitological Society, Warsaw, 9-12 September 2019, 155-156.

20. Ethylthiosulfanilate effect on Candida tropicalis / L.B. Oriabinska et $\begin{array}{lllllll}\text { al. Ukr.Biochem.J. 2017. № } 89 & \text { (5). } & \text { C. } & 70-76 . & \text { DOI: }\end{array}$ https://doi.org/10.15407/ubj89.05.070

21. Development of new antimicrobial compositions of thiosulfonate structure / V. Lubenets et al. Chemistry \& Chemical technology. 2013. Vol. 7. № 2. P. 119-124. URL: http://old.lp.edu.ua/fileadmin/ICCT/journal/ Vol.7/No_2/01.pdf 
22. Effects of thiosulfonates on the lipid composition of rat tissues / A.Z. Pylypets et al. Ukr.Biochem.J. 2017. № 89 (6). C. 58-64. DOI: https://doi.org/10.15407/ubj89.06.056

23. Баранович Д.Б., Лубенець В.І., Новіков В.П. Синтез S-алкіл 3,4-дизаміщених бензолтіосульфонатів і їх взаємодія 3 гідроксидом амонію. Укр. хім. журн. 1999. Т. 65 (12). С. 130-136.

24. Лубенець В.І., Баранович Д.Б., Новіков В.П. Тіосульфонати на основі оксифенілпохідних. Укр. хім. журн. 2001. № 67 (1). С. 45-48.

25. Патент на корисну модель № 64412. Застосування S-метил-4амінобензентіосульфонату як біоциду для захисту фарб та грунтовок / В.І. Лубенець та ін. и 201103717 ; заявл. 28.03.2011 ; опубл. 10.11.2011, Бюл. № 21.

26. Синтез и противомикробная активность эфиров 3,4дизамещенных бензолтиосульфокислот / В.И. Лубенец и др. Химикофарм. журнал. 2000. № 34 (3). С. 15-18.

27. Baranovich D.B., Lubenets V.I., Novikov V.P. Synthesis of Thiosulfonates with Functional Groups in the Aliphatic Chain. Russian Journal of Organic Chemistry. 2001. Vol. 37. № 7. C. 1046-1047. Translated from Zhurnal Organicheskoi Khimii. 2001. Vol. 37. № 7. C. 1093-1094. URL: https://doi.org/10.1023/A:1012499121615

28. Baranovich D.B., Lubenets V.I., Novikov V.P. Synthesis of S-[2-(4Aminobenzenesulfonyl)ethyl] and S-[2-(3-Amino-4-methoxybenzenesulfonyl)ethyl] Thiosulfonates. Russian Journal of General Chemistry. 2001. Vol. 71. № 11. C. 1827. Translated from Zhurnal Obshchei Khimii. 2001. Vol. 71. № 11. C. 1932. URL: https://doi.org/10.1023/ A:1013987618313

29. Синтез S-[2-(арилсульфоніл)етил]тіосульфонатів та їх гідроліз / В.I. Лубенець та ін. Укр. хім. журн. 2001. № 67 (12). С. 103-109.

30. Патент на винахід UA 63685 А. Україна. МПК 7 C07C381/00, C07C381/04. Заміщені арилсульфонілетилові S-естери тіосульфокислот, спосіб їх отримання, алкілуючі реагенти солей тіосульфокислот / В.І. Лубенець В.І. та ін. № 2003054921 ; заявл. 29.05.2003 ; опубл. 15.01.2004, Бюл. № 1.

31. A Comparison of the Antibacterial and Antifungal Activities of Thiosulfnate Analogues of Allicin / R. Leontiev et al. Scientific RePortS. 2018. 8. 1-19. DOI: 10.1038/s41598-018-25154-9

32. The human allicin-proteome: $\mathbf{S}$-thioallylation of proteins by the garlic defence substance allicin and its biological effects / C.H. Martin et al. Free Radical Biology and Medicine. 2019. 131. 144-153. URL: doi.org/10.1016/j.freeradbiomed.2018.11.022

33. Лабинская А.С. Микробиология с техникой микробиологических исследований. Москва : Медицина, 1972. 480 с.

34. Фунгібактерицидна активність деяких тіосульфоестерів / О.З. Комаровська та ін. Вісник НУ «Львівська політехніка». Хімія, технологія речовин та їх застосування. 2001. № 426. С. 137-140. 
35. Вивчення залежності біологічної активності тіосульфонатів від кислотної і тіольної складової / Д.Б. Баранович та ін. Вісник ДУ «Львівська політехніка». Хімія, технологія речовин та їх застосування. 2000. № 395. С. 96-99.

36. QNA-based 'Star Track' QSAR approach / D.A. Filimonov et al. Journal SAR and QSAR in Environmental Research. 2009. 20. 679-709. URL: https://doi.org/10.1080/10629360903438370

37. GUSAR software online. URL: http://www.pharmaexpert.ru/ GUSAR/AcuToxPredict/ (дата звернення: 04.03.2020).

38. Онкологія / за ред. Б.Т. Білинського, Ю.М. Стернюка, Я.В. Шпарика. Львів : Медицина світу, 1998. 272 с.

39. geneXplain platform. URL: http://genexplain.com/pass/ (дата звернення: 04.03.2020).

\section{Information about authors:}

Baranovych D. B.,

Candidate of Chemical Sciences, Associate Professor of Department of Technology of Biologically Active Substances, Pharmacy and Biotechnology Lviv Polytechnic National University 12, S. Bandery Str. Lviv, 79000, Ukraine

Lubenets V. I., Doctor of Chemical Sciences, Professor, Professor of the Department of Technology of Biologically Active Substances, Pharmacy and Biotechnology

Lviv Polytechnic National University 12, S. Bandery Str. Lviv, 79000, Ukraine 